Portland State University

PDXScholar

1985

\title{
The role of copper in the apparent aluminum toxicity of aquatic systems
}

Kirk Thomas O'Reilly

Portland State University

Follow this and additional works at: https://pdxscholar.library.pdx.edu/open_access_etds

Part of the Biology Commons, and the Plant Sciences Commons

Let us know how access to this document benefits you.

\section{Recommended Citation}

O'Reilly, Kirk Thomas, "The role of copper in the apparent aluminum toxicity of aquatic systems" (1985). Dissertations and Theses. Paper 3522.

https://doi.org/10.15760/etd.5406

This Thesis is brought to you for free and open access. It has been accepted for inclusion in Dissertations and Theses by an authorized administrator of PDXScholar. Please contact us if we can make this document more accessible: pdxscholar@pdx.edu. 
AN ABSTACT OE THE THESIS OF KIrk Thona o'Reilly for the Haster of Science in Blology presented May 24, 1985.

Title: The role of copper in the apperent aluminum toxicity of aquatic systene

APPROVED BY MEMBERS OF THE THESIS COMMITTEE:

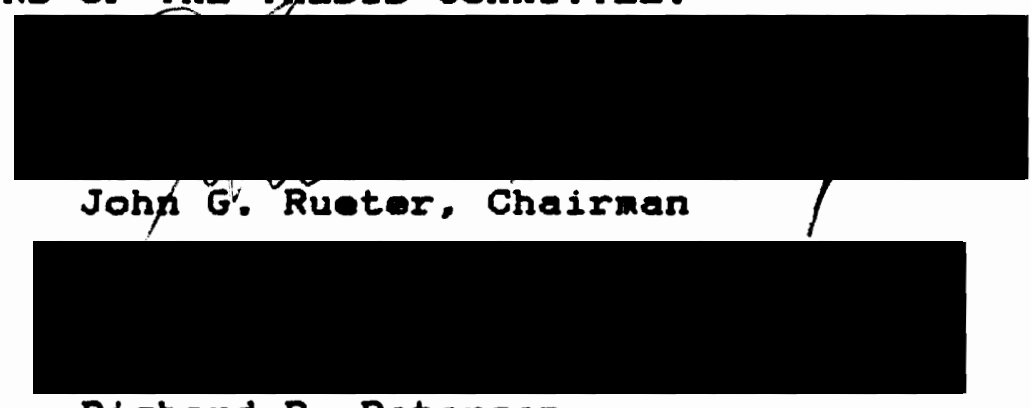

Richard R. Petersen

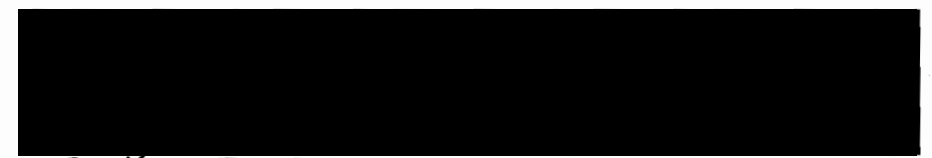

Byron E. Lippert

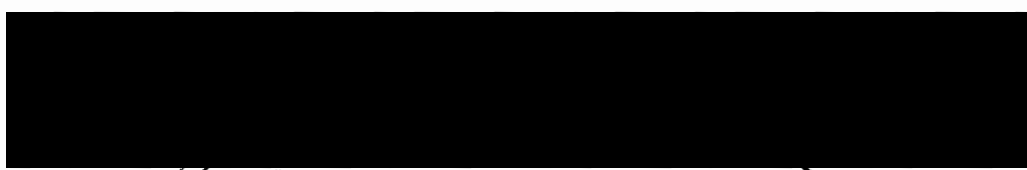

Eugone Ennoking

The effect of variationa in aluninum and copper concentrations on the growth rate and enzyme activity of the grean alga Scenedermus quadricauda was investigated. The goal was to determine whtch chemical epecies control the biological parametera. The computer program MINEQL (Westal et al 1976) was used to estimated chemical speciation. In the presences of both metals, algal growth rate and alkaline phosphatase activity could be correlated 
to cupric ion activity. The activity of isolated bacterial alkaline phosphatase was found to be a function of both total copper concentration and cupric ion activity. A model was developed to predicted the effects on alkaline phosphatase of perturbations in aquatic chemistry.

This research has environmental aignificance because the concentration of aluminum increases in some lakes affected by acid rain. Aluminum is thought to be responsible for some of the observed toxic effect in these systems. The results of this research support the hypothesis that the effect of aluminum may be due to its interaction with the metal chemistry; the increase in aluminum leads to an increase in the toxic apecies of other metals such as copper. 
THE ROLE OF COPPER IN THE APPARENT ALUMINUM TOXICITY OF AQUATIC SYSTEMS

by

KIRK THOMAS O'REILLY

A thesis submitted in partial fulfillment of the requirements for the degree of

\author{
MASTER OF SCIENCE \\ in \\ BIOLOGY
}

Portland State Univeraity 
TO THE OFFICE OF GRADUATE STUDIES AND RESEARCH:

The nembers of the Committee approve the thesis of K1rk Thomas O'Reilly presented May 24, 1985.
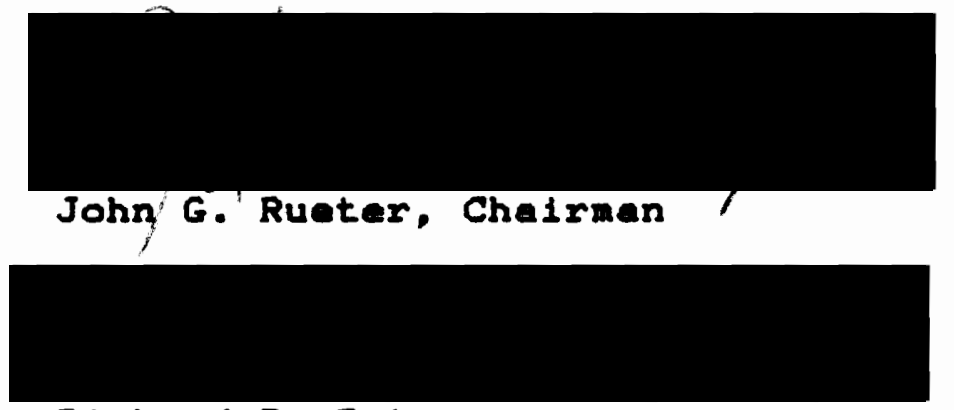

Richard R. Petersen

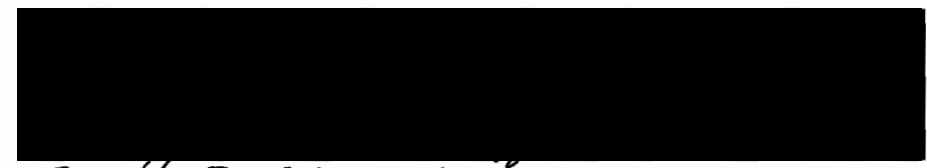

Byron E. Lippert

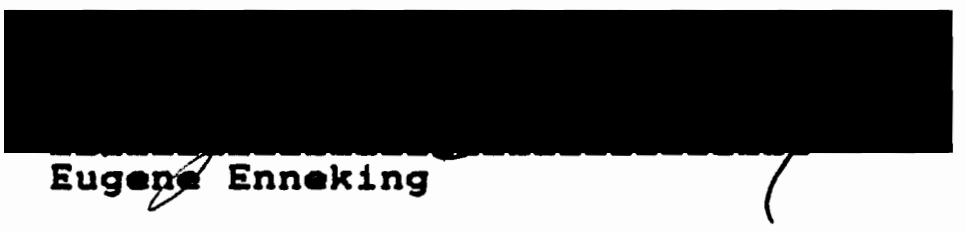

APPROVED:

w. Herman Taylor, Head, Depertmant of Blology

Jim(E. Feath, Dean of Graduate Studies and Research 
I would like to thank the members of my committee; John Rueter who taught me how to think like a scientist, Richard Petersen who made Oregon lakes come alive, and Ed Lippert who introduced me to his friends the algae.

I also thank the members of my family, especially Brin and Ron, for their support, help, and suggestions during my nineteen plus years as a student.

E. Quentin Welch acted as my trusted assistant during the growth rate experiments described in Chapter II. I thank him for his help and friendship. I also appreciate the help Casson Stalling gave me in dealing with computers. Finally, I would like to thank Kathryn Morrill for helping me keep sane by sharing my craziness. 
TABLE OF CONTENTS

PAGE

ACKNOWLEDGEMENTS......................111

LIST OF TABLES........................ vi

LIST OF FIGURES.......................

INTRODUCTION.......................... 1

CHAPTER I...........................

BACKGROUND

CHAPTER II........................... 14

THE GROWTH RATE OF SCEENDESMUUS QUAADRICEAUDA

AS A FUNCTION OF ALUMINUM AND COPPER

CHAPTER III........................... 28

ALKALINE PHOSPHATASE ACTIVITY AS A

FUNCTION OF THE AOUATIC CHEMISTRY

OF ALUMINUM, COPPER AND ZINC

CHAPTER IV.......................... 52

ALKALINE PHOSPATASE ACTIVITY IN SCEENEDESMUS:

INTERACTIONS OF ALUMINUM AND COPPER

CHAPTER $v \ldots \ldots \ldots \ldots \ldots \ldots \ldots \ldots \ldots \ldots \ldots \ldots \ldots \ldots \ldots \ldots . \ldots 6$

THE USE OF A COMPUTER MODEL TO PREDICT THE

INTERACTIONS OF COPPER AND ALKALINE PHOSPHATASE

CHAPTER VI.......................... 78

CONCLUSION 
APPENDIX A................................ 82

COPPER AND LACTATE DEHYDROGENASE:

INHIBITION OF AN INTERNAL ENZYME

REFERENCES................................... 89 


\section{LIST OF TABLES}

TABLE

PAGE

I Modified FRAQUIL medium............. 16

II Growth rate day ${ }^{-1}$ and $p C u$ for concentration of aluminum and copper.............. 19

II Enzyme buffers tested............... 31

IV Activity of alkaline phosphatase after twenty-four hours exposure to

aluminum and copper............... 35

$\checkmark$ Chemical components, species, and stability constants used in MICROQL........... 37

VI Activity of alkaline phosphatase at ten concentrations of aluminum and

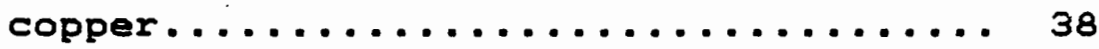

VII Reactivation of alkaline phosphatase after zinc addition................... 45

VIII Activity of Scennedesmus alkaline phosphatase and cupric ion activity as a function of aluminum and copper concentration..... 57

IX A comparison of experimental results with those predicted by MICROQL: zinc \& PNPP 67

$x$ A comparison of experimental results with those predicted by MICROQL: copper..... 70 
1. The growth rate day $y^{-1}$ of Scenegegengu gueㅁ도드늘 as a function of eluminum and copper concentration............ 20

2. The growth rate day ${ }^{-1}$ of Scenedegemus

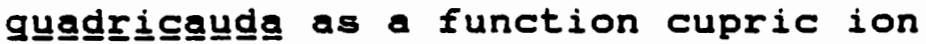
activity (pcu)................... 22

3. The activity of the cupric ion as a function of total aluminum........... 24

4. The growth rate day ${ }^{-1}$ of Scenedesmma

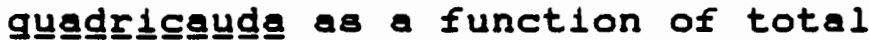
aluminum at a set copper concentration. 26

5. The activity of alkaline phosphatase in five buffers over twenty-four

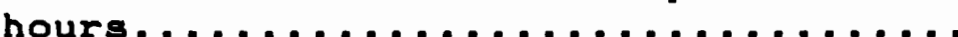

6. The activity of alkaline phosphatase as a function of aluminum concentration in the presence and absences of copper..........................

7. The activity of alkaline phosphatase as a function of cupric ion activity.... 41

8. A comparison of alkaline phosphatase activity at two zinc concentrations....

9. Reactivation of alkaline phosphatase activity after zinc addition..........4 46

10. The activity of Scenedesmus alkaline phosphatase as a function of aluminum concentration in the presence and

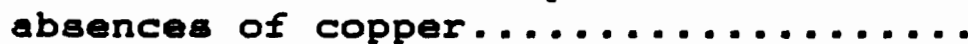

11. The activity of Scenedegmus alkaline phosphatase as a function of copper concentration at four aluminum

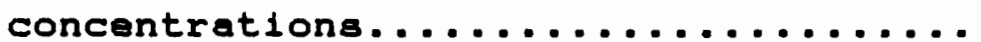




\section{LIST OF FIGURES}

cont.

12. The activity of Scenedesmus alkaline phosphatase as a function of cupric ion activity..................... 59

13. The activity of the cupric ion as a function of total aluminum........... 61

14. A comparison of experimental and predicted alkaline phosphatase activity at six zinc concentrations............... 72

15. A comparison of experimental and predicted alkaline phosphatase activity at four

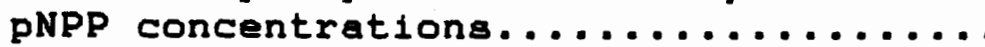

16. A comparison of experimental and predicted alkaline phosphatase activity at seven copper concentrations............... 


\section{INIROQDUCIION}

The goal of this project has been to investigate the effect of variations in the concentration of aluminum and

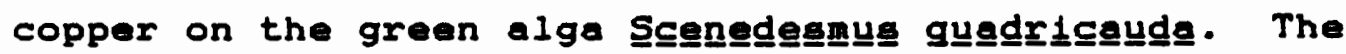
hypothesis is that the growth rate of the alga and the activity of its enzymes are related to the concentration of the free cupric ion. The research has environmental ignificance because of the increase in the aluminum concentration of lakes affected by acid rain. Aluminum is thought to be responsible for some of the observed toxicity in these systens. I will present evidence that the effect of aluminum may be due to its interaction with the metal chemistry; the increase in aluminum leada to an increase in the toxic form of another metal such as copper.

The background will begin with a description of the environmental conditions which lead to this research. The concept of chemical speciation will be introduced. The background will cover the theory of speciation, 1ts relationship to toxicity, and factors that control copper and aluminum speciation in the environment. This research is based on the understanding that the addition of one metal will affect the speciation of other metals in the systain. The use of computer programs to estimate the results of metal interactions will also be discussed. The final purpose of the background is to describe the test 
organism and enzyme system used to assay the effect of aluminum and copper.

The experiments performed to test the hypothesis are presented in chapters I through IV. The effect of variations in the concentration of aluminum and copper on

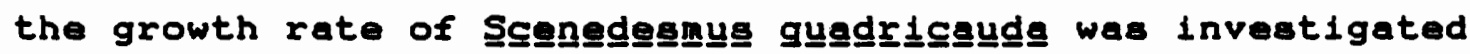
(Chepter II). The relationship between the concentration of these metals and the activity of the enzyme alkaline phosphatase was then studied. Experiments were performed

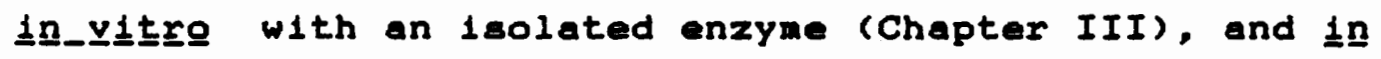
yivoo with Scenedesgus cultures (Chapter IV). In Chapter $V$, a model is developed to predict the effect of changes in metal speciation. 


\section{CHAPTER I}

BACKGROUND

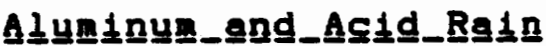

An environmentel effect of acid precipitation is the Increased mobility of aluminum (Driscoll et al 1984:

Lazerte 1984). Aluminum, a common component of soll, is insoluble at the natural pH of rain. Acid rain leads to the dissolution of aluminum compounds. Although this process neutralizes the ecidic input, it leads to an increase in diseolved aluminum (Johnson 1984). Increases in the concentration of this metal have been detacted in streams, lakes and ground water (Driscoll et al 1984). Acldifled lakes have been found to heve aluminum concentrations 10 to 50 times higher than neutral lakes in the sane region (Cronan and Schofield 1979).

The increase in aluminum is thought to be responsible for the loss of figh in lakes affected by acid rain (Dillon et al 1984). As acidity increases, toxic conditions may be produced by diseolved aluminum at pH levels that are not in themeelves harmful (Cronan and Schofield 1979). A statistical survey suggested that the aluminum concentration is the primary chemical factor controling the survival of fish (Schofield and Trojnar 1980). Although laboratory atudies have shown that it is possible to kill fish (Baker and Schofield 1982) and phytoplankton 
(Helliwell 1983) given high enough concentrations of aluminum, the mechenism of toxicity in the environment has not been demonstrated.

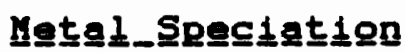

Metals can be present in a variety of chemical forms in natural waters. Each individual compound or complax is called a chemical species. The total concentration of a netal is the sum of the concentrations of its free and complexed species. The relative concentration of each species depends on the chemical interactions of all the reactive components of a system. The important factors controliing metal apeciation is the relationship between the number of ligands available for metal complexation and the total concentration of metal.

There is chemical competition for complexation if two metals can reversibly bind to the same site. This competition can be represented by the equation:

$$
\mathrm{Me}_{1}-\mathrm{L}+\mathrm{Me} 2<==\approx==\mathrm{Me} e_{1}+\mathrm{Me}_{2}-\mathrm{L}
$$

An increase in the concentration of either metal will cause the free ion concentration of both metals to 1ncrease. The free metal activity is often reported as the negative log concentration or pHe. This convention is analogous to $\mathrm{pH}$. 
The interactions of metals in aquatic solutions can be modeled ueing computer programe (Westall et al 1976; Fontaine 1984). These programe are used to estimate the equilibrium concentration of the various chemical species. The programs used in this research are MINEQL (Westall et al 1976) and MICROOL (Westall 1979). These are basically the same progran designed for mainframe and micro computers reapectively. The input for these programs consista of the concentration of chemical components of a solution and the equilibrium or stability constants for all the poseible interactions of the components. Components are defined in such a way that all poselble species can be written a products of reactions involving only components. The computer performe a series of equilibrium calculations until the mass balance error la below an acceptable level. The output consists of the concentration of each species. Although MICROOL is a valuable tool for determining chenical speciation in the laboratory, it does have limitatione for environmental application. It cen only be accurately ueed for solutions in which the exact concentration of each component is known. Also stability constants are necessary for all the possible chemical interactions. This information ia not generally available for natural waters. The program assumes that equilibrium 18 reached between all of the specles which may not be valid for a dynamic natural aysten (Fontaine 1984). 


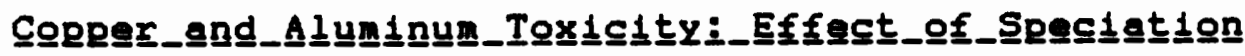

Copper $1 \mathrm{~s}$ toxic to organisms of many taxonomic groups In aquetic ecosyatems. Phytoplankton (Peterson et al 1984), zooplankton (Glesy at al 1983), and fish (Shaw and Brown 1973) have all been shown to be ausceptible to copper toxicity. Natural levels of copper can inhibit algal growth. Huntsmen and Sunda (1980) state there is - Increesing evidence for the toxicity of copper even in unpolluted weter'. Steeman-Nielson and Wium-Andersen (1970) found copper to be poisonous at concentrations found In natural watera.

Chemical speciation 18 critical in determining the effect of metals in aquatic ecosystems. Only certain metal species interact with the biota. The activity of the free cupric ion $\left(\mathrm{Cu}^{+2}\right)$ is thought to be the primary factor determining the toxicity of copper to phytoplankton (reviewed in: Huntsman and Sunda 1980) and fish (Shaw and Brown 1973). Organic complexation decreases copper toxicity (Peterson et al 1984). Algel growth rate (Petersen 1982), enzyme activity (Rueter 1983), and nutrient uptake (Rueter and Morel 81) cen all be related to the free cupric ion concentration.

The relative toxicity of different aluminum species is not well understood beceuse chemical conditions have not been well controlled in aluminum toxicity studies. Some believe that the free metal ion is the toxic species 
(Burrows 1977), while others clain $A 1(\mathrm{OH})_{2}^{+} 18$ the most toxic form (Helliwell 1983). Organically complexed aluminum is essentially non-toxic (Johnson et al 1984). Variations in the chenistry of a solution can lead to toxicity of a matal without an increase in the total concentration of that metal. Copper toxicity has been shown to increase by decreasing the concentration of natural complexing agente (Sunda and Lewis 1978). Petersen (1982) demonstrated that the addition of zinc can lead to copper toxicity in algal culture. Zinc competes and displaces sone copper from the chelator present in the mediun thus increesing the cupric ion concentration. Aluminum may exert 1ts effect by similar mechanisms in natural syatems.

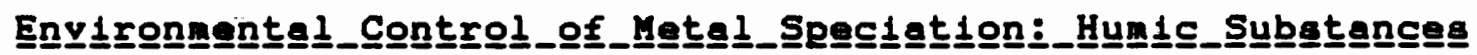

The environmental application of the results of this research depends on the reversible complexation of metals in lakes. Due to the presence of a diverse erray of organic and inorganic Iigands in natural waters, a number of compounde could be important in the complexation capacity of an aquetic systen (Perdue 1979). Both copper (Shaw and Brown 1973) and aluminum (Lazerte 1984) are naturally found as free metal lons, inorganic species, and as organic complexes with biological compounds.

Humic substances are a class of compounds which have been shown to be Important in metal complexation (Gamble et al 1983). Terrestrial plant material is the primary source 
of these compounds. The presence of various branched carbon chains preventa further degradation by microorganisms. Humic substances are often the most prevalent organics in aquatic systems (Perdue 1979). These polymeric compounds are heterogeneous in terms of molecular weight, number of binding sites, and stability of metal complexes (Giesy et al 1983). Hunics are effective chelators due to the presence of carboxyl, alcoholic, ketolic, and phenolic groups (Giesy 1983).

Although humic substances have been shown to form complexes with metals, the interaction can not be characterized with defined stability constants (Perdue and Lytle 1983; Giesy 1983; Saer and Weber 1982). This is partially due to the fact that humics are a class of different compounds, although attempts to separate them for individual study has proven to be unsuccessful (Perdue and Lytle 1983). Metal-humic interactions are best described by experimentally derived conditional atability constanta and maximum binding capacities (Giesy et al 1983). Generally the derived values are only valid for humics from a particular environment. The stability constant is also influenced by $\mathrm{pH}$ due to proton-humic interactions (Perdue 1983).

Humic substances have been shown to be important in determining copper speciation and toxicity in natural waters (Glesy et al 1983, McKnight 1981, Huntaman and Sunda 1980). Copper can form atable complexes with a variety of 
organic ligands. The complexation of copper with humics can be described by the equation:

$\mathrm{Cu}^{+2}+\operatorname{humic-H}<=z=\equiv>$ humic-Cu$+\mathrm{H}^{+}$

Thus the activity of copper is determined by the concentration of humics, competing metals, and the pH. Giesy (1983), Mcknight (1981), and Gatcher at al (1978) all found that a majority of the total dissolved copper in various lakes is associated with humics. Uncomplexed copper is generally the second most prevalent species. As discussed earlier, humic bound copper is unavailable to phytoplankton and does not lead to toxicity. Glesy (1983) and HcKnight (1981) state that humic complexation is an important factor controlling copper toxicity to phytoplankton.

Metal lona compete with one another for binding sites; increasing the concentration of one metal increases the free ion concentration of others by displacenent (Gamble et al 1983). Due to the chemical uncertainty of these compounds and differences in humic substances from different environments it is not possible to predict the exact outcome of competition between aluminum and copper in natural waters. A generalized order of metal-hunic stabilities is Al > Cu based on competition for binding sites (Giesy 1983). Giesy found that aluminum would displace copper from humics axtracted from various sites in South Carolina. Kerndorff and Schnitzer (1980) allowed eleven metals to simultaneously interact with a humic solution. Although the results varied with pH, the 
conditional binding of aluminum is similar to that of

copper. Of the eleven metals tested both aluminum and copper were found to have intermediate affinity for humics. Although the displacement of copper by aluminum has not been shown in a natural system, it should occur given the similar affinities that the two metals have for humic complexation.

In this research, the synthetic chelators EDTA (Ethylenedinitrilotetracetic acid) and NTA (Nitrilotriacetic acid) were used to model the actions of humic substances. Previous studies have shown this to be a useful approach. Davey et al (1973) found the results of algal bioesseys in natural water could be calibrated by comparison to similar results in media containing EDTA. Gillespie and Vaccaro (1978) used a bacterial bioassay and found similarities in the effects of natural organics and EDTA on decreasing copper toxicity. Sunda and Lewis (1978) grew phytoplankton in media containing copper and various concentrations of humic substances and obtained the results predicted using synthetic chelator models. A complicating factor is that a high concentration of EDTA may be toxic to algae (Rueter, pers. comm.)

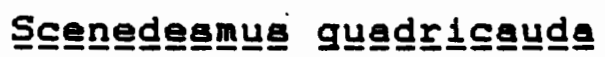

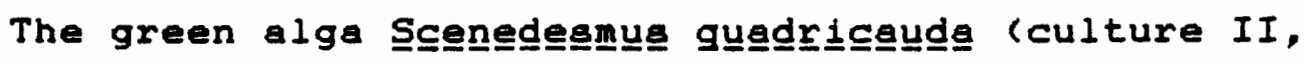
Freshwater Institute, Winnipeg, Canada) was used as a test organism in this research. It was chosen because of its 
use in similar experiments (Petersen 1982). Its taxonomic position is (Bold and Wynne 1978):

Division- Chlorophycophyta

Order- Chlorellales

Family- Scenedesmaceae

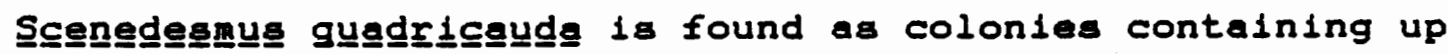
to four cells. The cell are joined laterally, and the terminal cells often have two spikes protruding from the ends. The number of cells per colony in laboratory cultures is influenced by the media used (Bold and Wynne 1978). Four and one cells per colony were the most common

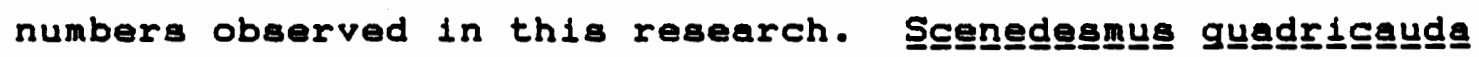
are widely distributed in freshwater habitats.

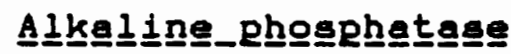

Metel toxicity can be expressed as an inhibition of any critical cellular process (Peterson et al 1984). I chose to measure the activity of alkaline phosphatase for a varlety of reasons. Alkaline phosphatase has been shown to be a biochemical marker of metal toxicity (Rueter 1983). It is important in the environmental success of phytoplankton (Currie and Kalft 1984). The enzyme is associated with the surface of algae so it is in direct contact with the chemistry of the medium (Rueter 1983). Alkaline phosphatase is known to be a zinc metallo-enzyme (Coleman and Gettins 1983) which allows for modeling of 
the interactions between the toxic netals and the zinc binding site.

Alkaline phosphatase $1 \mathrm{~s}$ found in a wide variety of taxonomic groups. Isolated enzymes from verious opecies have been atudied and they share the same basic properties (Coleman and Gettins 1983). The enzyme is a dimer with a molecular weight of about 95,000. At least two zinc lons are associated with each dimer (Cohen and Wilson 1966). Alkaline phosphatase is a nonspecific phosphomonoesterase (Coleman and Gettins 83) which catalyzes the hydrolysis of orthophosphate from a wide variety of organic phosphate compounds.

Alkaline phosphatase activity can be eritical in controlling the success of phytoplankton species (Currie and Kalft 1984a). Phosphorus is often the resource liniting phytoplankton growth in lakes (Goldman and Horne 1983). Alkaline phosphetase is required to utilize dissolved organic phosphate (DOP), which may be the primary source of phosphorus for phytoplankton (Currie and Kalft 1984a,b). Because of a faster uptake rate, bacteria utilize over 97x of the inorganic phosphate. If metal toxicity decreases the activity of alkeline phosphatase, it would lead to a decrease in phosphorus avallability to phytoplenkton.

Alkaline phosphatase has been shown to be a blochemical marker of copper toxicity (Rueter, 1983). This effect can be detected using a purified enzyme 
solution, cell free algal extract, or active algal culture. The activity of the enzyme decreases in relation to an increase in the cupric ion concentration. The effect is thought to be due to the displacement of the native zinc ion by copper. Both metals form divalent cations with similar lonic radil and bonding geometries (Vallee 1958).

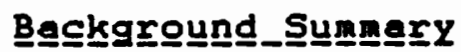

Acid rein leads to an increase in the concentration of aluminum in some lakes. My goal is to present evidence that the observed effect of increased aluminum may be due to the interaction of this metal with the aqueous chemistry of the systen. The toxicity of a metal can be related to the concentration of a particular chenical species of the metal. In aquatic systems, the free metal ion is often the most toxic form. Thia form is often found in low concentration due to complexation with humic substances. Aluminum may exert its effect by competing for binding sites with more toxic metals auch as copper. This would lead to an increase in the toxic form of copper without an increase in the total copper concentration. This hypothesis is tested by investigating the effect various concentrations of aluminum and copper have on algal growth rate and enzyme activity. Changes in these biological parameters should relate to variations in metal speciation. 


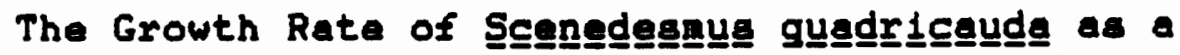
function of aluminum and copper concentration

\section{INTRODUCTION}

The goal of this experiment is to determine the

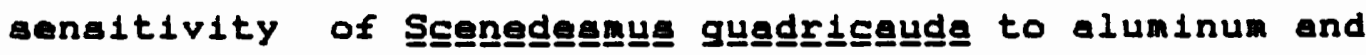
copper toxicity. The alga is grown in media containing various concentrations of aluminum and copper. The growth rate will be compared to the total concentration of each metal as well as the free lon activity of each metal. The hypothesis is that the growth rate should be related to the activity of the free cupric ion.

The design of this experiment is based on work done on the same organism by Petersen (1982). In his experiments, Petersen investigated the effect variations in zinc and copper concentration had on algal growth rate. Growth data was analyzed in terms of total concentration as well as the estimated chemical speciation. He found that in the presence of both metale, the observed toxicity could be related to the free cupric ion.

\section{METHODS}

Care must be taken with experiments on the effects of trace metals to prevent metal contamination. Nanopure water obtained from a Barnstead system was used in all 
experiments. Plasticware was allowed to soak in $4 \times \mathrm{HCL}$ for 24 hours and rinsed five times with Nanopure water immediately prior to use. The growth medium was a run through a column of Chelex 100 (Bio-red lab.). This cation exchange material removes any metal contaminates present in the solution. All culture manipulations were performed in a laminar hood (Environmental Air Control Inc.). Clean plastic gloves were worn while handling the culture flasks.

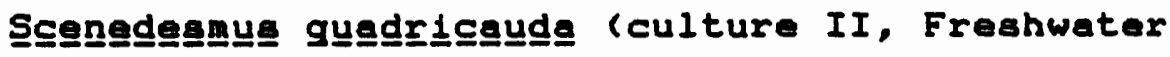
Institute algal culture collection. Freshwater Institute, Winnipeg, Canada) was used as the test organiam. The algae were grown in Fraquil (Morel et al, 1979), as modified by Petersen (1982). The chenical composition of the mediun is listed in Table I. $1000 x$ concentration stocks of the nutrienta; $\mathrm{NaS}_{4}, \mathrm{~K}_{2} \mathrm{HPO}_{3}, \mathrm{NaNO}_{3}$ and the major lons; $\mathrm{CaCl}_{2}$, $\mathrm{KgSO}_{3}$, and $\mathrm{NaHCO}_{3}$ were prepared. A metal stock solution which contained $1 \times 10^{-3}$ EDTA and $1000 x$ concentration of the metals (excluding $C u$ and $A l$ ) listad in table $I$ was also prepared. Two milliliters of each nutrient stock were diluted to one liter with Nanopure water. The major ions were similarly mixed. The nutrient mix and the ion solution were run through separate Chelex columns. soo ml of each chelexed solution were combined and $1 \mathrm{ml}$ of the metal stock was added to produce one liter of Fraquil. The medium was filter aterilized using a 0.45 uM filter (Nucleopore Co.). 
TABLE I

\section{MODIFIED FRAQUIL CULTURE MEDIA}

\begin{tabular}{lccc}
$\begin{array}{l}\text { chemical } \\
\text { concentration } \\
\text { component }\end{array}$ & $\begin{array}{c}\text { concentration } \\
\mathrm{mol} / \mathrm{L}\end{array}$ & $\begin{array}{l}\text { chemical } \\
\text { component }\end{array}$ & $\mathrm{mol} / \mathrm{L}$ \\
\hline $\mathrm{Ca}^{+2}$ & $2.5 \times 10^{-4}$ & $\mathrm{CO}_{3}^{-2}$ & $1.5 \times 10^{-4}$ \\
$\mathrm{Mg}^{+2}$ & $1.5 \times 10^{-4}$ & $\mathrm{SO}^{-}$ & $1.5 \times 10^{-4}$ \\
$\mathrm{~K}^{+}$ & $2.0 \times 10^{-5}$ & $\mathrm{Cl}^{-}$ & $5.2 \times 10^{-4}$ \\
$\mathrm{Fe}^{+3}$ & $4.5 \times 10^{-7}$ & $\mathrm{B(OH}_{4}^{-}$ & $1.0 \times 10^{-7}$ \\
$\mathrm{Mn}^{+2}$ & $2.3 \times 10^{-8}$ & $\mathrm{MoO}_{4}^{-2}$ & $1.5 \times 10^{-9}$ \\
$\mathrm{Co}^{+2}$ & $2.5 \times 10^{-9}$ & $\mathrm{NO}_{3}^{-}$ & $1.0 \times 10^{-4}$ \\
$\mathrm{Zn}^{+2}$ & $1.0 \times 10^{-9}$ & $\mathrm{EDTA}^{-4}$ & $5.0 \times 10^{-6}$ \\
$\mathrm{NH}_{3}$ & $1.3 \times 10^{-9}$ & $\mathrm{Al}^{+3}$ & variable \\
$\mathrm{H}^{+}$ & variable & $\mathrm{Cu}^{+2}$ & variable
\end{tabular}

Concentration of the componente of the medie Fraquil (Morel et al 1979) as modified by Petersen (1982). $\mathrm{H}^{+}$ concentration ( $\mathrm{pH}$ 5-8) was variable due to changes in the aluminum and copper concentrations. 
Stock solutions of $1 \times 10^{-1} \mathrm{M} \mathrm{AlCl}_{3}$ and $5 \times 10^{-2} \mathrm{M} \mathrm{CuSO}_{4}$ were used as the source of these metals. $100 \mathrm{ml}$ of mediun ateach experimental concentration was made in $250 \mathrm{ml}$ Teflon flasks. These solutions were allowed to sit for twenty-four hours before experiments were performed ao equilibrium between the metals and EDTA could be obtained. The growth experiments were performed in $30 \mathrm{ml}$ polycarbonate tubes. $20 \mathrm{~m}$ aliquots of medium were inoculated with $0.2 \mathrm{ml}$ of a atationary phase maintenance culture of

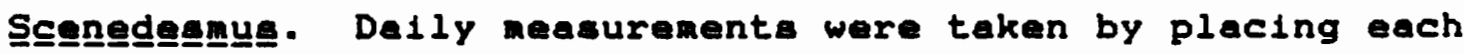
tube in a fluorometer (Turner Designs, Model 10) set to detect the fluorescence of chlorophyll a:

light source- bulb F4T5

excitation filter- c/s 5-60

emision filter-c/s 2-64

The Increase in chl a fluorescence was used as the measurement of growth. The cultures were kept in an Incubator (Environator Co.) at $18^{\circ} \mathrm{C}$. The light was continuous and had an intensity of $100 \mathrm{u}$ Einsteins $\mathrm{m}^{-2} \mathrm{~s}^{-1}$. The tubes were kept in clear plastic racks and ahaken at $100 \mathrm{rpm}$. Each growth experiment lasted 7 days. The exponential phase of growth was determined by graphing the dally fluorescence on seni-log paper. Growth rate was deternined using the equation:

$$
u=\left(\ln E_{2}-\ln F_{1}\right)+(\# \text { days })
$$

$u=$ growth rate

$F_{1}=$ fluorescence on first day of exponential growth 
$E_{2}=$ fluorescence on last day of exponential growth

$F^{2}=$ number of deys between $F_{1}$ and $F_{2}$

The effect of aluminum and copper on algal growth rate was first determined individually. After the effective level of each matal was known, a matrix of metal concentratione were derived (Table II). The copper concentrations used in these experinents were $0,3,4,4.5$, and $5 \times 10^{-6} \mathrm{M}$, while the aluminum concentrations were 0,2 , 3, 4, 5, 6, and $8 \times 10^{-6} \mathrm{M}$. The growth rate was determined for thirty three concentration combinations of these metal concentrations (table II).

The concentrations of the chemical apecies at each set of aluminum and copper concentrations were estinated using the computer progran MINIQL (Weatall et al 1976). Critical equilibrium constants involving EDTA, aluminum, and copper were compered to other published values (Smith and Mertell 1975).

\section{RESULTS}

Although individual cultures had growth rates as high as $0.93 \mathrm{day}^{-1}$, the average Umax for any concentration combination was 0.85 . The control cultures with no additional netals always had growth rates about 0.2 units lower than cultures with low concentrations of aluminum or copper. Additional metal did not have a noticeable effect on growth rate until a threshold concentration 1 s reached 
TABLE II

GROWTH RATE DAY-1 (upper) AND pCu (lower) AS ESTIMATED BY MINIQL (Westall et al 1976), FOR EACH CONCENTRATION OF

ALUMINUM AND COPPER

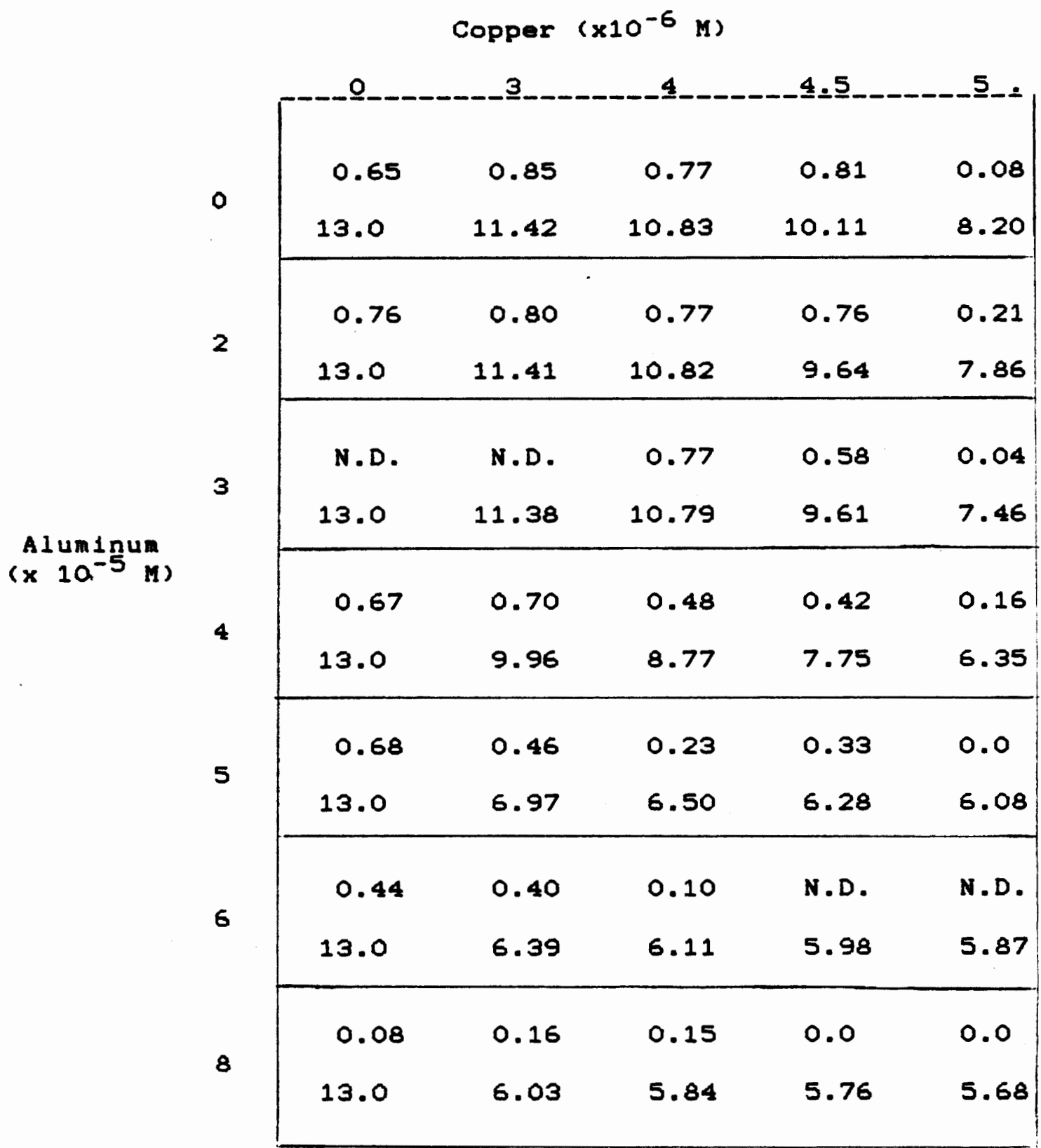

N.D. - no data 


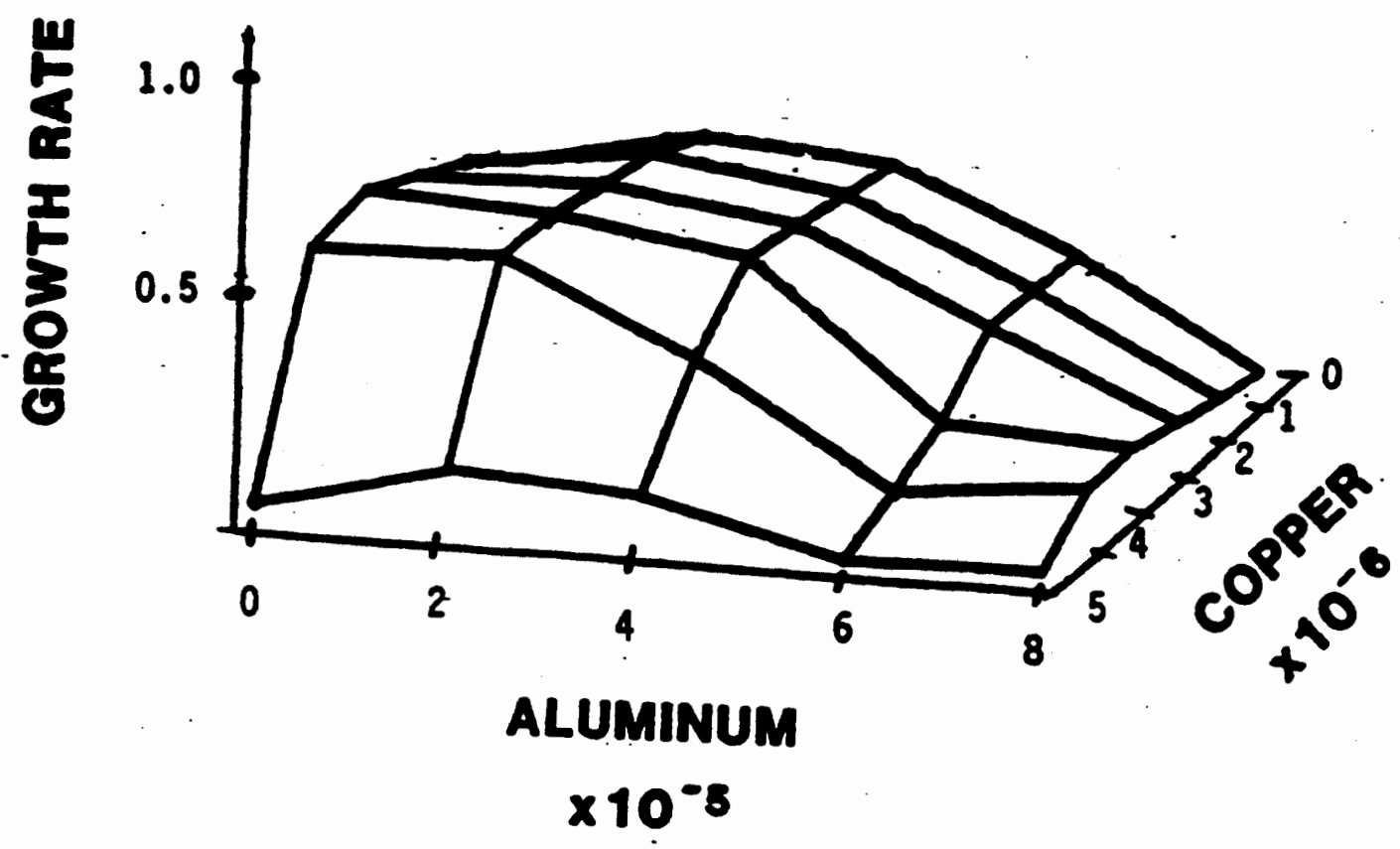

E1gurs-1. The growth rate day ${ }^{-1}$ of Sgenedegmus as a function of the total concentration of aluminum and copper. 
(Table II ; Figure 1). Above this level the growth rate decreases dramatically. The threshold concentration of both aluminum and copper depends on the concentration of the other netal.

The $E_{50}$ (effective concentration-50x) is the concentration of a metal at which the growth rate of the alga is fifty percent of maximum. The Al-EC 50 in the absence of copper $1 \mathrm{~s}$ about $6 \times 10^{-5} \mathrm{M}$. As the amount of copper increases, the Al-EC 50 decreases (Figure 1). At higher copper concentrations, less aluminum is required to inhibit growth. The Al-EC 50 can not be determined if the copper concentration $185 \times 10^{-6} \mathrm{M}$ since the growth rate in the absence of aluminum is less than $50 x$ of the control rate. The growth rate is alightly higher at this copper concentration if some aluminum is present.

At aluminum concentrations below $2 \times 10^{-5} \mathrm{M}$, the $\mathrm{Cu}$ $E_{50}$ is between 4.5 and $5 \times 10^{-6} \mathrm{M}$. If the aluminum concentration is raised to $3 \times 10^{-6} \mathrm{M}, 4.5 \times 10^{-6} \mathrm{M}$ copper 1 eads to a 25x decrease in growth rate. The Cu-EC 50 is about $4 \times 10^{-}$ 6 If the aluminum concentration $1 \mathrm{~s} 4 \times 10^{-5} \mathrm{M}$. It drops to $3 \times 10^{-6} \mathrm{M}$ copper at $5 \times 10^{-5} \mathrm{M}$ aluminum. As the growth rate at $6 \times 10^{-5} \mathrm{M}$ aluminum 18 only about $50 x$ of the control, it is not possible to determine an Cu-EC50. At this aluminum concentration, the growth rate remains fairly constant until the copper concentration exceeds $3 \times 10^{-6} \mathrm{M}$. 


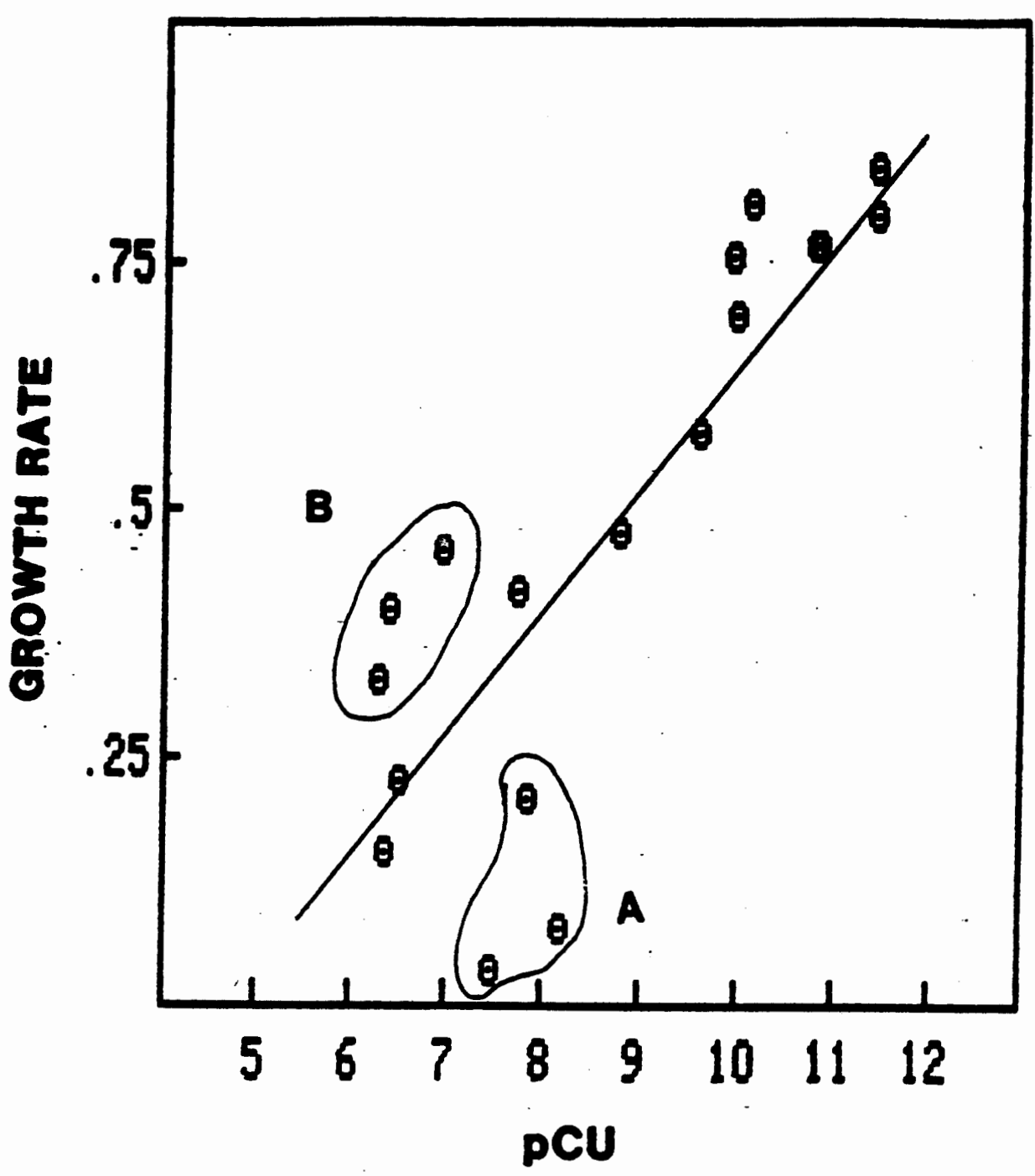

E1gurs_2. The growth rate day ${ }^{-1}$ of Seenedesaus as a function of cupric ion ectivity (pCu). See the discussion for a deceription of $A$ and $B$. 
At the highest aluninum concentration tested, the growth rate was slightly higher at copper concentrations of 3 and $4 \times 10^{-6}$ M than in the absence of copper.

A statistical correlation $\left(r^{2}=0.87\right)$ was determined between the log concentration of the cupric ion (pCu) and the growth rate of Scenegdesㅛㅡㅂㅗ (F1gure 2). Linear regression analysis revealed no such correlation between the growth rate and pAl $\left(r^{2}=0.46\right)$, pH $\left(r^{2}=0.56\right)$, or any of the other species. As the growth rate changed due to variations in the concentration of either metal, a relationahip between the total concentration of a metal and the growth rate was not obtained.

\section{DISCUSSION}

Cupric ion activity is the chemical factor controliting the growth rate of Scenedegemug. Aluminum exerts its effect by competing with copper for organic binding sites. As the aluminum concentration increases, copper lons are displaced from EDTA and the cupric ion activity increases. The effect of competition between aluminum and copper for complexation is demonstrated in figure 3 . At a set copper concentration, the activity of the cupric ion increases (pCu decreases) with aluminum concentration.

The results obtained agree with published results from a similar experiment with copper and zinc (Petersen 1982). He found that in the presence of copper, an increase in 


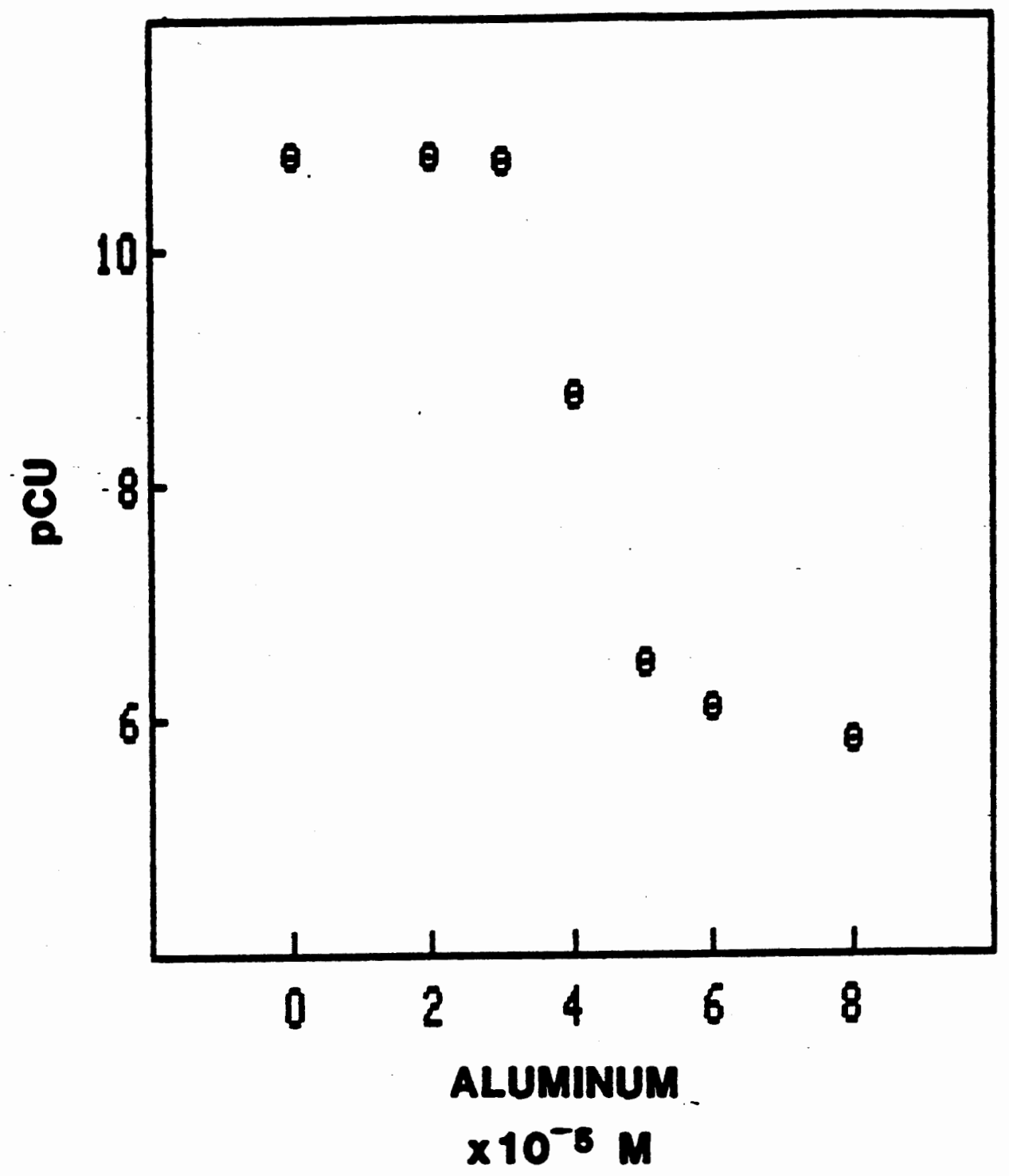

Eigure-3. The activity of the cupric lon increases with aluminum concentration. The copper concentration is set at $4 \times 10^{-6}$ copper. 
zinc could lead to increesed copper toxicity. The effect was thought to be due to the displacenent of copper ions from EDTA. An important point is that although two metals may individually inhibit the growth of Scenendesmmus speciation must be known to determine the toxic agent in the presence of both metala.

Although a good correlation is obtained between growth rate and cupric ion ectivity, figure 2 shows two sets of data that appear to vary from remainder of the samples. The three data points labeled $A$ are all cultures that contained the highest copper concentration $\left(5 \times 10^{-6} \mathrm{M}\right)$. The total copper concentration may be important in determining toxicity at this level. Also, at $5 \times 10^{-6} \mathrm{M}$ the concentration of copper and EDTA are equal. EDTA'B effectiveness as a buffer depends on the relative concentration of the metal and the chelator. If the buffering capacity is exceeded, the cupric ion activity could fluctuate and cause higher values than estimated by MINEQL .

The cultures labeled B all contalned $2 \times 10^{-5} \mathrm{M}$ aluminum. The growth rate of these cultures was higher than predicted. A low concentration of aluminum may provide protection from copper toxicity. Evidence of an protective effect of aluminum was also found in experiments on the effect of aluminum and copper on the activity of alkaline phosphatase (Chapter III). 


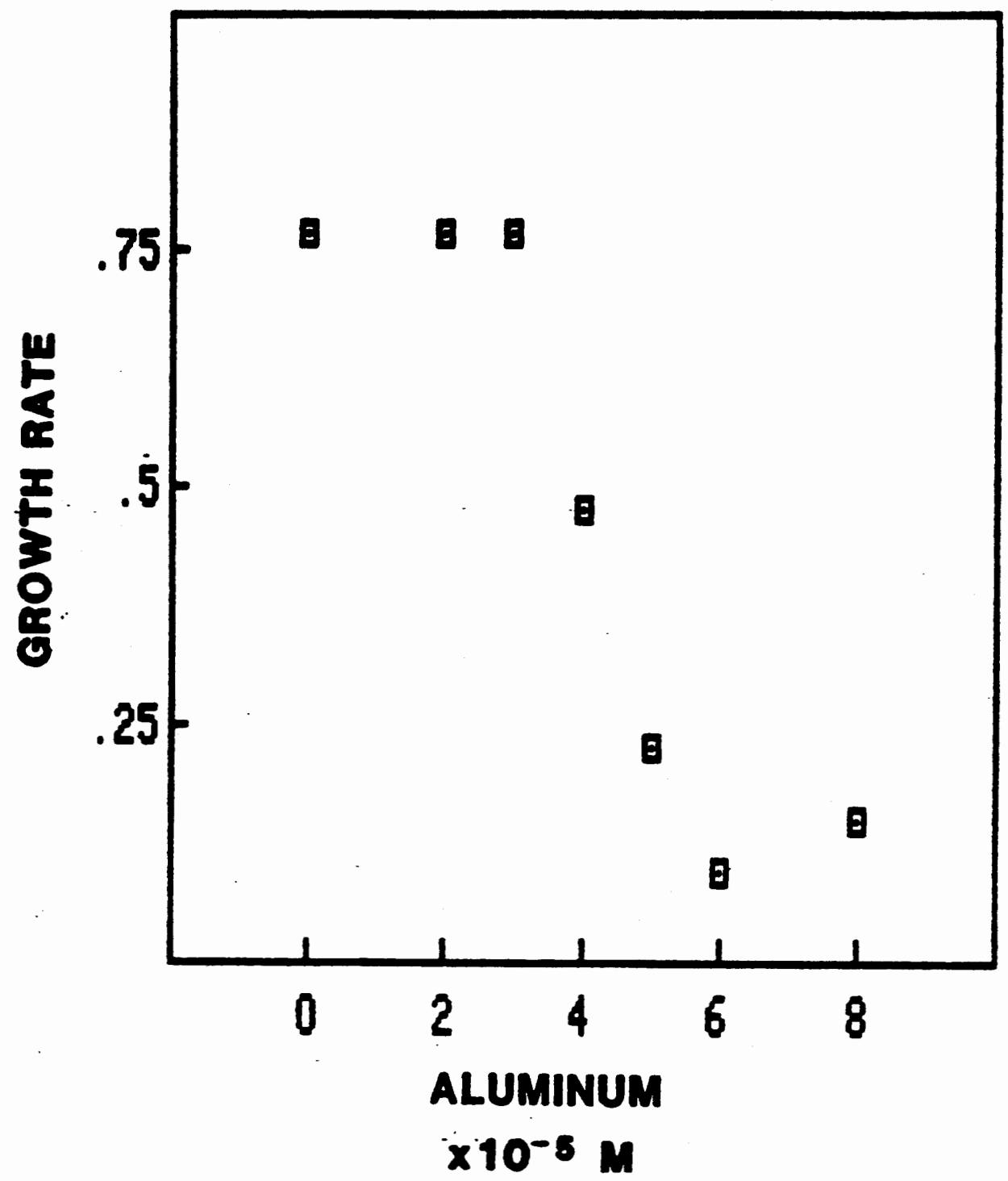

Elgure-4. The growth rate day ${ }^{-1}$ of Scenedgemene as a function of total aluminum. The copper concentration is set at $4 \times 10^{-6} \mathrm{M}$ copper. Although an increase in aluminum does lead to a decrease in growth rate, this research has shown the cupric ion to reaponalble for the toxic effect. 
Although there is a statistical relationship between the increase in aluminum and a loss of fish CCronan \& Schofield 1979), the information is not avaliable to determine what changes in metal speciation may have occurred. Evidence of cause and effect can be misleading if the data is incomplete. Field data often consist only of changes in $\mathrm{pH}$ and total aluninum concentration. If a lake subjected to acid rain is modeled by a set of cultures with the same copper concentrations but different amounts of aluminum, toxicity does appear to increase with aluminum concentration (Figure 4). But the results of this experiment show that the toxicity is not due directly to aluminum but to changes in the aquatic chemistry.

\section{CONCLUSION}

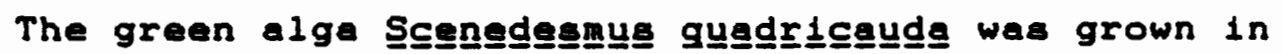
thirty three different concentrations of aluminum and copper. The growth rate of the alga was compared to the total concentration of each metal, as well as, estinates of metal speciation. Growth rate was found to be related to the cupric ion activity. Aluminum alone has a minimal toxic effect. The results support the hypothesis that the observed effect of increased aluminum may be due to interactions with the aquatic chemistry of a aystem. 


\section{CHAPTER III}

\section{ALKALINE PHOSPHATASE ACTIVITY AS A FUNCTION OF THE AQUATIC CHEMISTRY OF ALUMINUM, COPPER, AND ZINC}

\section{INTRODUCTION}

This research attempts to characterize the interactions between aluminum and copper in relation to the toxicity of these metals. The hypothesis predicts that metal speciation is more important than the total metal concentration. In this chapter, the inhibition of alkaline phosphatase is used as an indicator of toxicity. This enzyme was chosen because it is important in the phosphate nutrition of algae (Currie and Kalft 1984) and it has been shown to be a biochemical marker of metal toxicity (Rueter 1982).

The use of enzyme activity assays has benefits over cell growth rate experiments in metal toxicity studies. The chemistry of the media can be simplified without concern for the nutritional requirements of cells. Algae may release organic chelators which complicate metal speciation calculations (Mcknight and Morel 1979). Another benefit is that enzyme studies take less time so more experiments can be performed.

Three types of experiments were performed in this investigation. Ten enzyme buffers solutions were tested to 
deternine their suitability in trace metal studies. The activity of alkaline phosphatase as a function of aluminum and copper concentration was determined. The results of those experiments suggested that zinc present in the buffer effects enzyme activity. The final set of experiments investigates if alkaline phosphatase inhibition due to zinc removal is reversible.

\author{
SECTION 1 \\ Enzyme Buffer Solutions
}

METHODS

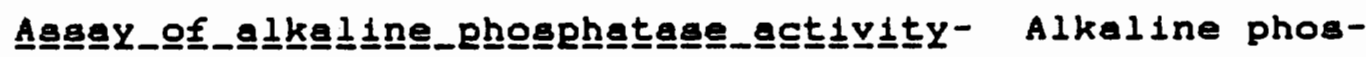
phatase, isolated from E._Coli (Sigma Co), was diluted to one unit, ml in $1 \times 10^{-3} \mathrm{M} \operatorname{Tr} 1 \mathrm{~s}(\mathrm{pH} 8.3$ ) and stored at 5 ${ }^{\circ} \mathrm{C}$. $0.1 \mathrm{ml}$ of the enzyme-Tris solution was added per $10 \mathrm{ml}$ of the experimental buffer solution. The final concentration of the enzyme was $1 \times 10^{-2}$ units, ml. $2.5 \mathrm{ml}$ of the enzyme-buffer was added to a $1 \mathrm{~cm}$ path length cuvette. Enzyme assays were started by adding $0.1 \mathrm{ml}$ of $1 \times 10^{-3} \mathrm{M}$ n-Nitrophenylphosphate (pNPP)(Sigma Co). The hydrolysis of PNPP was followed at $410 \mathrm{~nm}$ in a spectrophotometer (Baush \& Lomb, Spectronic 100) over four minutes. An absorbance change of 0.001 corresponded to a $1.4 \times 10^{-7} \mathrm{M}$ change in pNPP concentration. 


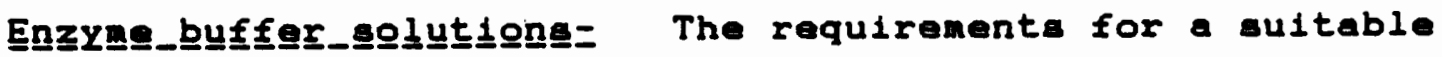
enzyme buffer include: the enzyme must have measurable activity in the solution; the enzyme must remain active over time: the $\mathrm{pH}$ must be maintained within the range of 7.5 to 8.0 ; it must permit free metal activities to be fixed at effective total metal concentrations; and the equilibrium constants between all the components and aluminum and copper must be known so estimates of metal speciation can be readily calculated.

Ten buffers were tested to deternine their suitability in metal toxicity studies (Table III). Experimental buffers were prepared by diluting concentrated stock solutions. Buffers were allowed to st at least four hours before assays were performed. Assays were performed over a twenty-four hour period.

\section{RESULTS}

The activity of the enzyme was higher in $1 \times 10^{-3} \mathrm{M}$ Tris ( $1.3 \times 10^{-6} \mathrm{M}$ pNPP / min) than in any of the subsequent buffers (Table III). The activity showed little chenge over twenty-four hours. A set of experiments were performed to compere the use of EDTA and Tris. Four solutions were tested: $1 \times 10^{-3}$ M Tris, $1 \times 10^{-3}$ M EDTA, 1 $\times 10^{-3} M \operatorname{Tr} 18+1 \times 10^{-6} M$ EDTA, and $1 \times 10^{-3} M \operatorname{Tr} 18+1 \times 10^{-5}$ M EDTA. The activity of alkaline phosphatase appeared to be inhibited by EDTA (Figure 5). 
TABLE III

ENZYME BUFFERS TESTED

\begin{tabular}{|c|c|c|c|c|c|}
\hline $\begin{array}{l}\text { Chemi } \\
\text { compos. }\end{array}$ & & & $\left(\times 10^{-\frac{A}{7}}\right.$ & $\begin{array}{l}\text { ity } \\
\text { NPP } / \pi\end{array}$ & Comments \\
\hline $1 \times 10^{-3}$ & $\boldsymbol{M}$ & tris & 25.2 & 21.0 & $\begin{array}{l}\text { equilibrium constant not } \\
\text { available for Al-tris }\end{array}$ \\
\hline $\begin{array}{l}1 \times 10^{-3} \\
1 \times 10^{-6}\end{array}$ & $\begin{array}{l}M \\
M\end{array}$ & $\begin{array}{l}\operatorname{tris} \\
\text { EDTA }\end{array}$ & 19.6 & 13.7 & $\begin{array}{c}\text { apparent inhibition } \\
\text { due to EDTA }\end{array}$ \\
\hline $\begin{array}{l}1 \times 10^{-3} \\
1 \times 10^{-5}\end{array}$ & $M$ & $\begin{array}{l}\operatorname{tris} \\
\text { EDTA }\end{array}$ & 18.2 & 5.6 & $\begin{array}{c}\text { apparent inhibition } \\
\text { due to EDTA }\end{array}$ \\
\hline $1 \times 10^{-3}$ & $\mathbf{M}$ & EDTA & 11.3 & 3.9 & $\begin{array}{c}\text { apperent inhibition } \\
\text { due to EDTA }\end{array}$ \\
\hline $\begin{array}{l}1 \times 10^{-4} \\
1 \times 10^{-5} \\
1 \times 10^{-8}\end{array}$ & $\begin{array}{l}\mathbf{M} \\
\mathbf{M} \\
\mathbf{M}\end{array}$ & $\begin{array}{l}\mathrm{NaHCO}_{3} \\
\text { EDTA } \\
\mathrm{ZnCl}\end{array}$ & 3.6 &.-- & $\begin{array}{c}\text { ionic strength } \\
\text { too low }\end{array}$ \\
\hline $\begin{array}{l}1 \times 10^{-3} \\
1 \times 10^{-5} \\
1 \times 10^{-8}\end{array}$ & $\begin{array}{l}\mathbf{M} \\
\mathbf{M} \\
\mathbf{M}\end{array}$ & $\begin{array}{l}\mathrm{NaHCO}_{3} \\
\text { EDTA } \\
\mathrm{ZnCl}\end{array}$ & 14.0 & 7.0 & $\begin{array}{l}\text { ZnCl does not prevent } \\
\text { EDTA inactivation }\end{array}$ \\
\hline $1 \times 10^{-3}$ & $\mathbf{M}$ & NTA & 0.0 &.- & $\begin{array}{l}\text { NTA solution is not } \\
\text { a suitable buffer }\end{array}$ \\
\hline $\begin{array}{l}1 \times 10^{-3} \\
1 \times 10^{-5} \\
1 \times 10^{-8}\end{array}$ & $\begin{array}{l}\mathbf{M} \\
\mathbf{M} \\
\mathbf{M}\end{array}$ & $\begin{array}{l}\mathrm{NaHCO}_{3} \\
\mathrm{NTA} \\
\mathrm{ZnCl}\end{array}$ & 18.2 & 16.8 & effective buffer \\
\hline $\begin{array}{l}1 \times 10^{-3} \\
1 \times 10^{-5} \\
1 \times 10^{-8} \\
1 \times 10^{-3}\end{array}$ & $\begin{array}{l}M \\
M \\
M \\
M\end{array}$ & $\begin{array}{l}\mathrm{NaHCO}_{3} \\
\mathrm{NTA} \\
\mathrm{ZnCl} \\
\mathrm{CaCl}_{2}\end{array}$ & 17.6 & 5.6 & activity not maintained \\
\hline $\begin{array}{l}1 \times 10^{-3} \\
1 \times 10^{-5}\end{array}$ & $M$ & $\begin{array}{l}\mathrm{NaHCO}_{3} \\
\mathrm{NTA}\end{array}$ & 18.1 & 16.8 & effective buffer \\
\hline
\end{tabular}




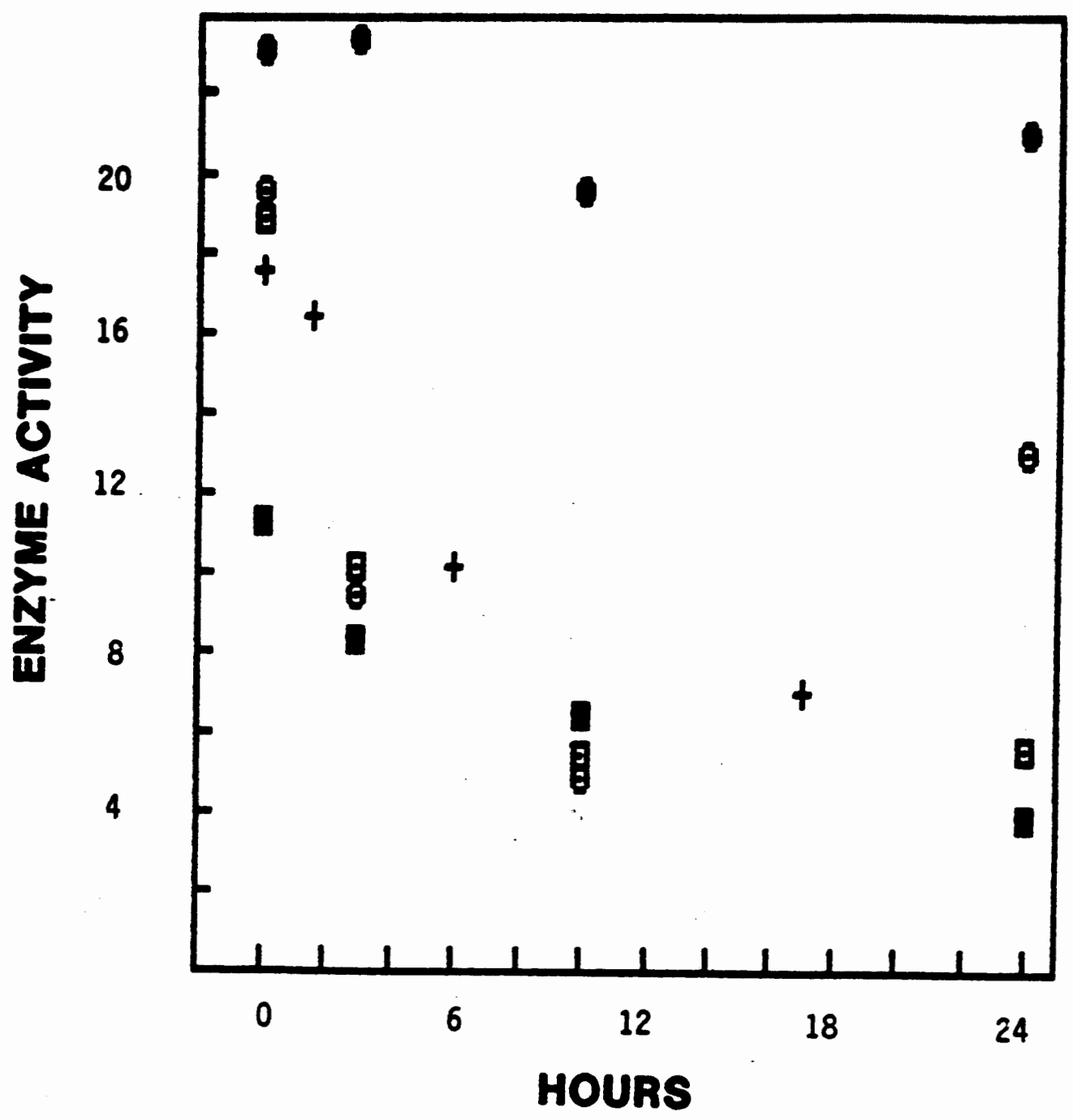

Figure_5. The activity of alkaline phosphatase $\left(\times 10^{-7}\right.$ INPP,$m i n)$ in five buffets over twenty-four hours.
$\theta-1 \times 10^{-3}$ Tr1e, $1 \times 10^{-6}$ EDTA
1. $1 \times 10^{-3}$ Tr10
E - $1 \times 10^{-3}$ Trie, $1 \times 10^{-5}$ EDTA
1 - $1 \times 10^{-3}$ EDTA
t - $1 \times 10^{-3} \mathrm{NeHCO}_{3}, 1 \times 10^{-3} \mathrm{CaCl}_{2}, 1 \times 10^{-5} \mathrm{NTA}, 1 \times 10^{-8} \mathrm{ZnCl}$ 
Buffer AP-B contained $1 \times 10^{-4} \mathrm{M} \mathrm{NaHCO}, 1 \times 10^{-5} \mathrm{M}$ EDTA, and $1 \times 10^{-8} \mathrm{M}$ ZnCl. The measured activity wes 1.1 $\times 10^{-7}$ pNNP / min. This 1 s only 10 percent of the activity found in $1 \times 10^{-3}$ Tris. The activity increased about seven fold to $7 \times 10^{-7} \mathrm{M}$ pNNP, min if the concentration of $\mathrm{NaHCO}_{3}$ was raised to $1 \times 10^{-3} \mathrm{M}$. After three hours the activity in this solution decreased by 50 percent.

The decrease in activity was not noted when the EDTA was replaced by NTA. The activity of the enzyme in Buffer $\mathrm{AP}-\mathrm{D}\left(1 \times 10^{-3} \mathrm{M} \mathrm{NaHCO}, 1 \times 10^{-5} \mathrm{MNTA}\right.$, and $\left.1 \times 10^{-8} \mathrm{M} \mathrm{ZnCl}\right)$ was about $18.2 \times 10^{-7} \mathrm{M}$ pNNP $/ \mathrm{min}$ and remained constant for four days. Although Buffer AP-D appeared to be satisfactory, two variations were tested. In an attempt to lower the amount of aluminum and copper required to cause enzyme inhibition, $\mathrm{Ca}^{+2}$ was tested as a competing ion. Although the activity of alkaline phosphatase in Buffer AP-E (Buffer $A P-D+1 \times 10^{-3} \mathrm{M} \mathrm{CaCl}_{2}$ ) at time zero and two hours was similar to the activity in Buffer AP-D, it dropped by fifty percent at six hours. The activity continued to decrease with time (Figure 5). Buffer AP-F was a ZnCl free version of AP-D. The activity of the enzyme in AP-F was similar to the results in $A P-D$. Buffer $A P-D\left(1 \times 10^{-3} \mathrm{M} \mathrm{NaHCO}, 3\right.$ $\times 10^{-5} \mathrm{M} N \mathrm{NT}$, and $1 \times 10^{-8} \mathrm{M} \mathrm{ZnCl}$ ) was chosen as the buffer to use in the aluminum and copper experiments. 
SECTION 2

Aluminum and Copper

METHODS

Alkaline phosphatase was exposed to ten aluminumcopper concentration combinations. Assays were performed over twenty-four hours. The activity of the enzyme was compared to both the total concentration and calculated metal ion activities.

The experimental concentrations of aluminum and copper were $0,2,4$, and $6 \times 10^{-5} \mathrm{M}$. Ten different combinations of the two metals were tested (Table IV). In all cases, the total metal concentration did not exceed $6 \times 10^{-5} \mathrm{M}$. Stock solutions of $\mathrm{AlCl}_{3}\left(1 \times 10^{-2} \mathrm{M}\right)$ and $\mathrm{CuSO}_{4}\left(5 \times 10^{-2} \mathrm{M}\right)$ were added to 100 milliliters of the buffer to make each concentration combination. The pH of each solution was measured (Orion Research, Ionalyzer 404) and adjusted to 7.7 with $0.1 \mathrm{M} \mathrm{NaOH}$. The solutions were allowed to sit for 12 hour before the enzyme assay. $10 \mathrm{ml}$ of each metal combination was placed in $30 \mathrm{ml}$ polycarbonate tubes. At time zero, $0.1 \mathrm{ml}$ of the enzyme-Tris solution was added to each tube. Assays were performed at time zero, 2 hours, 8 hours, and twenty four hours.

Copper is thought to inhibit alkaline phosphatase by displacing the native zinc ion. The result of competition between the two metals should depend on the relative activities of copper and zinc. The zinc concentration in 
TABLE IV

ACTIVITY OF ALKALINE PHOSPHATASE AFTER

TWENTY-FOUR HOURS EXPOSURE TO

ALUMINUM AND COPPER

\begin{tabular}{|c|c|c|c|c|c|}
\hline $\begin{array}{l}\text { copper } \\
\times 10^{-5}\end{array}$ & $\begin{array}{l}\text { aluminum } \\
\times 10^{-5}\end{array}$ & \multicolumn{4}{|c|}{$\begin{aligned} \text { experimently determined activity } \\
\times 10^{-3} \text { pNPP / min }\end{aligned}$} \\
\hline 0 & 0 & 17.2 & 17.6 & 15.8 & 15.8 \\
\hline 2 & 0 & 14.0 & 12.6 & 13.2 & 10.2 \\
\hline 4 & 0 & 5.6 & 6.0 & 10.6 & 8.4 \\
\hline 6 & 0 & 3.6 & 3.6 & 4.2 & 3.2 \\
\hline 0 & 2 & 17.6 & 16.8 & 16.2 & 16.8 \\
\hline 2 & 2 & 7.0 & 6.0 & 6.4 & 6.4 \\
\hline 4 & 2 & 6.4 & 4.6 & 4.6 & 4.6 \\
\hline 0 & 4 & 16.2 & 15.8 & 14.0 & 14.8 \\
\hline 2 & 4 & 6.4 & 6.4 & 8.4 & 8.4 \\
\hline 0 & 6 & 14.8 & 15.8 & 13.5 & 10.2 \\
\hline
\end{tabular}


the aluminum-copper buffers discussed above was raised from $1 \times 10^{-8} \mathrm{M}$. to $1 \times 10^{-6} \mathrm{M}$. After twenty-four hours exposure to increased zinc, the assays were repeated. The results obtained at the two zinc concentrations were compared.

The chemical speciation for each sample was estimated using a Pascal version of MICROQL (Westall 1985). The program was run on a Zenith 151 PC (Zenith data systems). A matrix (Table V) was set up for the component of the buffer. The stability constants used were obtained from the MINEaL progran data file (Westall et al 1976).

RESULTS

Four data sets were avallable for each metal concentration combination (Table IV). The difference in activity between data sets was usually less than $2 \times 10^{-7}$ M PNPP , min. An exception was the sample with $4 \times 10^{-5} \mathrm{M}$ copper: the data between the experimental runs differed by $5 \times 10^{-7}$ $M$ pNPP $/ \min \left(r a n g e: 5.6-10.6 \times 10^{-7} \mathrm{M}\right.$ pNPP, min). The study was repeated for all the samples containing only copper. The activity determined at $4 \times 10^{-5} \mathrm{M}$ copper (4.9 \& $7.3 \times 10^{-7} \mathrm{M}$ pNPP, $\mathrm{min}$ ) suggests the lower activities were more accurate.

Individually aluminum and copper produced different effects on the activity of alkeline phosphatase (Table VI). The presence of copper led to an immediate inhibition of the enzyme. Linear regression analysis indicates that 
TABLE V

CHEMICAL COMPONENTS, SPECIES, AND

STABILITY CONSTANTS USED

IN MICROQL

Components- NTA, $\mathrm{Zn}^{+2}, \mathrm{Al}^{+3}, \mathrm{Cu}^{+2}, \mathrm{H}^{+}$

\begin{tabular}{|c|c|c|c|}
\hline \multicolumn{2}{|c|}{ Speçie日___- } & \multicolumn{2}{|c|}{ 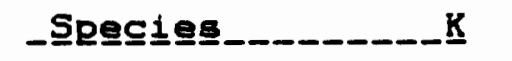 } \\
\hline NTA & 0.0 & NTA-H & 10.41 \\
\hline - NTA-H 2 & 13.55 & NTA $-\mathrm{H}_{3}$ & 15.72 \\
\hline $\mathbf{z n}$ & 0.0 & $\mathrm{ZnOH}$ & -9.53 \\
\hline$Z n-N T A$ & 12.22 & $2 n-N T A_{2}$ & 14.11 \\
\hline $\mathrm{Cu}$ & 0.0 & $\mathrm{CuOH}$ & -7.84 \\
\hline Cu-NTA & 14.32 & CUOH-NTA & 4.78 \\
\hline $\mathrm{Cu}-\mathrm{NTA}_{2}$ & 17.01 & Al & 0.0 \\
\hline AI-NTA & 14.53 & ALOH-NTA & 9.16 \\
\hline AlOH & -4.56 & $\mathrm{~A}_{1}-\mathrm{NTA}_{2}$ & 20.53 \\
\hline $\mathrm{OH}$ & -14.00 & & \\
\hline
\end{tabular}


TABLE VI

\section{ACTIVITY OF ALKALINE PHOSPHATASE \\ AT TEN ALUMINUM-COPPER \\ CONCENTRATIONS}

\begin{tabular}{|c|c|c|c|c|c|}
\hline $\begin{array}{l}\text { copper } \\
\text { activity } \\
\times 10^{-5} \\
\frac{M}{}\end{array}$ & $\begin{array}{r}\text { aluminum } \\
\times 10^{-5}\end{array}$ & $\mathrm{pCu}^{+2}$ & $\mathrm{pAI}^{+3}$ & activity & $24 \mathrm{hr}$ \\
\hline 0 & 0 &.-- &.-- & 15.5 & 16.6 \\
\hline 2 & 0 & 5.24 &.-- & 11.3 & 12.6 \\
\hline 4 & 0 & 4.76 &.-- & 11.2 & 5.8 \\
\hline 6 & 0 & 4.54 &.-- & 9.5 & 3.7 \\
\hline 0 & 2 &.-- & 8.14 & 16.4 & 16.8 \\
\hline 2 & 2 & 5.11 & 7.92 & 14.4 & 6.5 \\
\hline 4 & 2 & 4.74 & 7.88 & 11.6 & 4.7 \\
\hline 0 & 4 &.-- & 7.66 & 17.0 & 15.2 \\
\hline 2 & 4 & 5.06 & 7.60 & 14.8 & 7.4 \\
\hline 0 & 6 &.-- & 7.44 & 16.2 & 13.0 \\
\hline
\end{tabular}

activity $=x 10^{-7} \mathrm{M}$ PNPP $/$ min 
the activity rate decreases $0.92 \times 10^{-7}$ M pNPP / min per 1 $\times 10^{-5}$ M copper $\left(x^{2}=0.88\right)$. The inhibition increased with time so that by twenty-four hours the enzyme activity compared to control is lower by $2.2 \times 10^{-7} \mathrm{M}$ pNPP, min per $1 \times 10^{-5}$ a copper $\left(r^{2}=0.97\right)$.

The experimental concentrations of aluminum did not immediately inhibit the activity of alkaline phosphatase. At time zero, enzyme activity appeared to increase alightly with aluminum concentration, but with a $r^{2}$ value of 0.55 this was not significant. After twenty-four hours, the activity of the enzyme decresses $0.4 \times 10^{-7} \mathrm{M}$ pNPP / min per $1 \times 10^{-5}$ aluminum $\left(r^{2}=0.73\right)$. This is only about one fifth the decrease caused by the same amount of copper.

The effect of increasing aluminum at a set copper concentration changed with time. For example, if the copper was $2 \times 10^{-5} \mathrm{M}$, an increase of aluminum led to an activity increase of $0.8 \times 10^{-7} \mathrm{M}$ PNPP $/ \min$ per $1 \times 10^{-5} \mathrm{M}$ at time zero $\left(r^{2}=0.85\right)$. The aluminum may protect the enzyme from immediate copper inhibition. After twenty-four hours, an increase in aluminum led to an inhibition similar to an increase in copper. The activity dropped $1.14 \times 10^{-}$ 7 pNPp / min per $1 \times 10^{-5} \mathrm{M}$ aluminum (Figure 6). The Inhibition 1: 400 percent greater than caused by aluminum alone.

An analysis of all the data indicates that alkaline phosphatase activity is related $\left(r^{2}=0.78\right)$ to cupric ion 


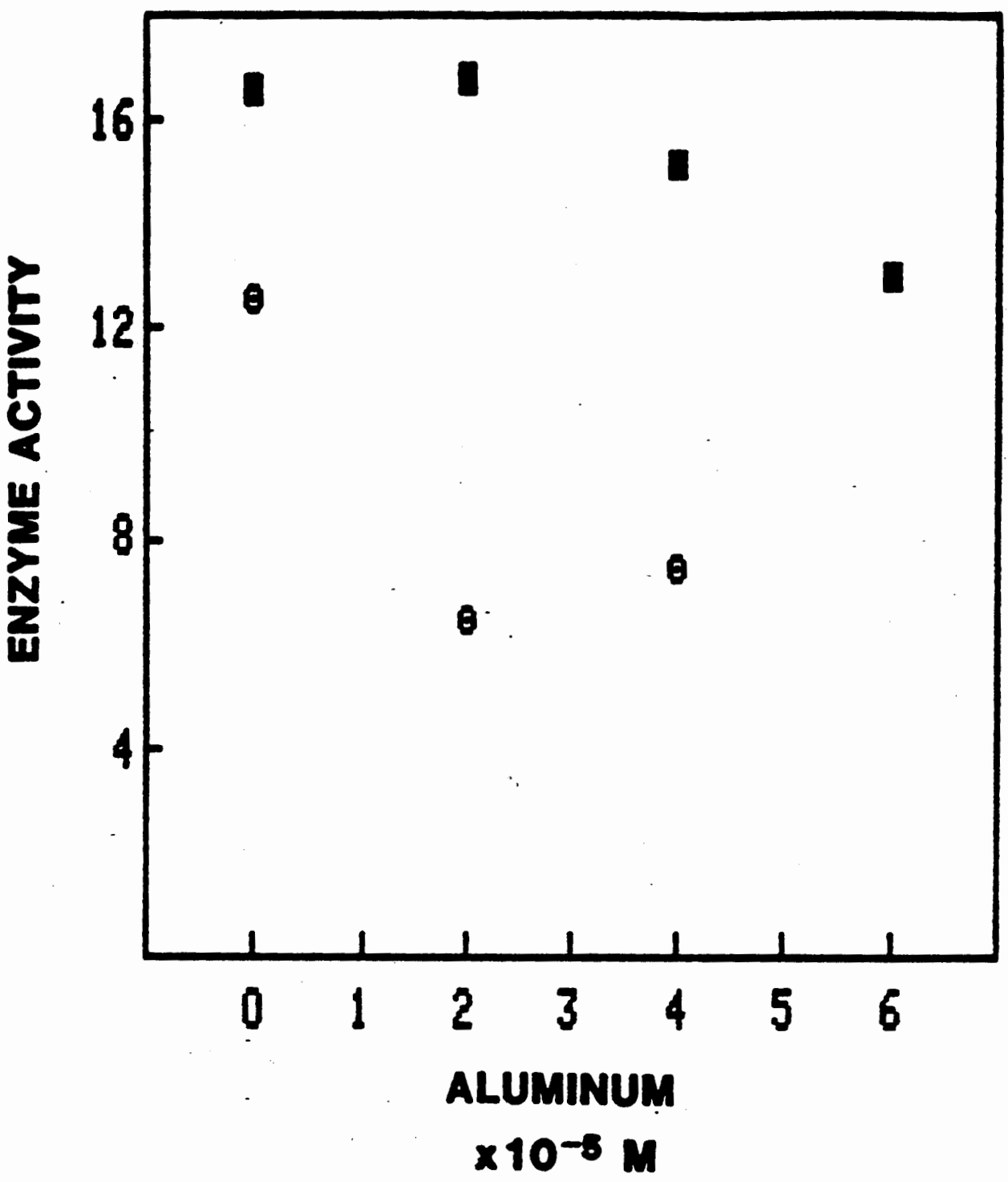

E1gures-6. The activity of alkaline phosphatase $\left(\times 10^{-7}\right.$ M PNPP,$M i n)$ as a function of aluminum concentration in the presences and absences of copper.

- no copper

6- $2 \times 10-5 \times$ copper 


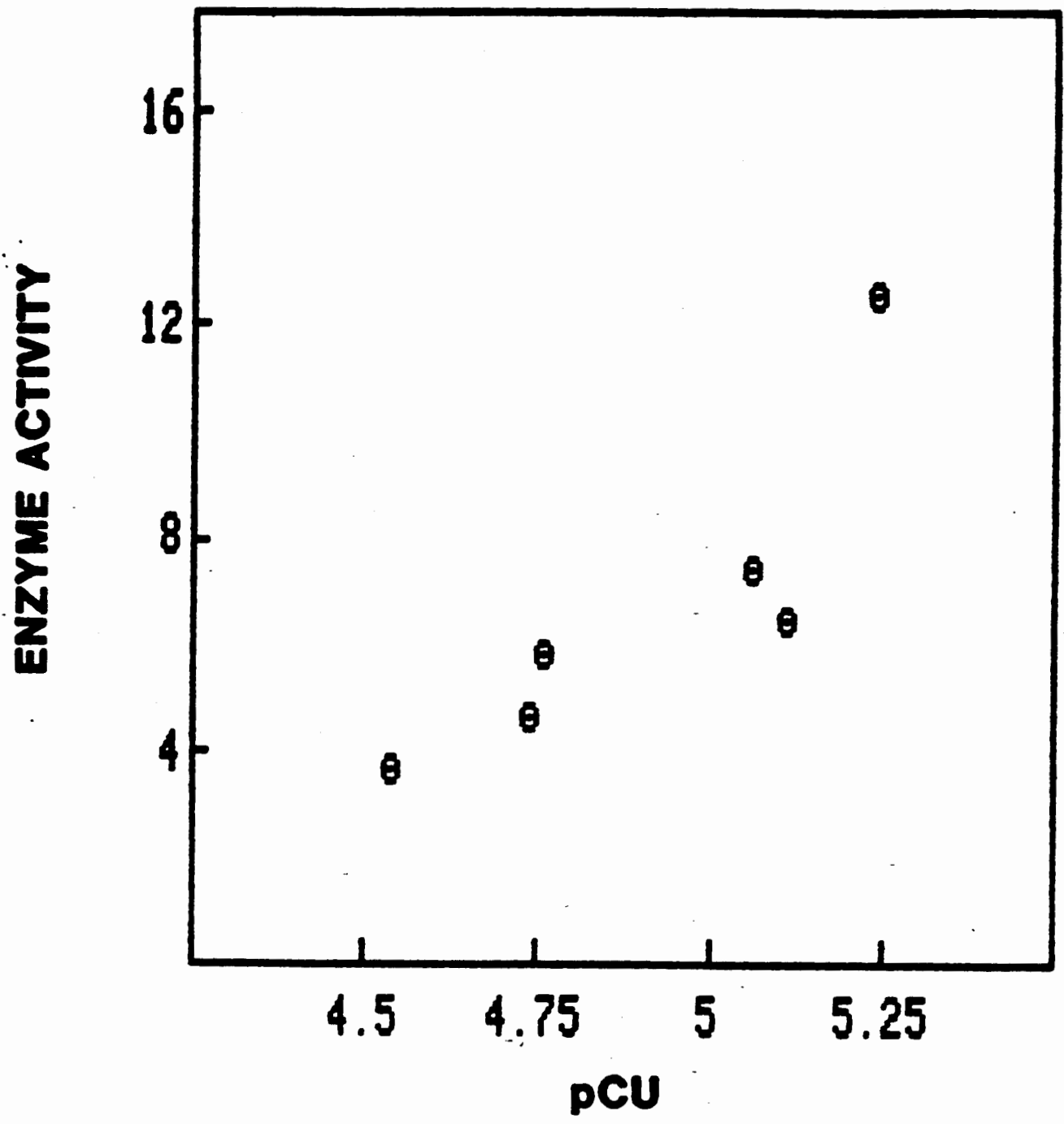

Elgure_z. The activity of alkaline phosphatase $\left(\times 10^{-7}\right.$ H pNPP, $-1 n$ ) as a function of cupric lon activity (pCu). 


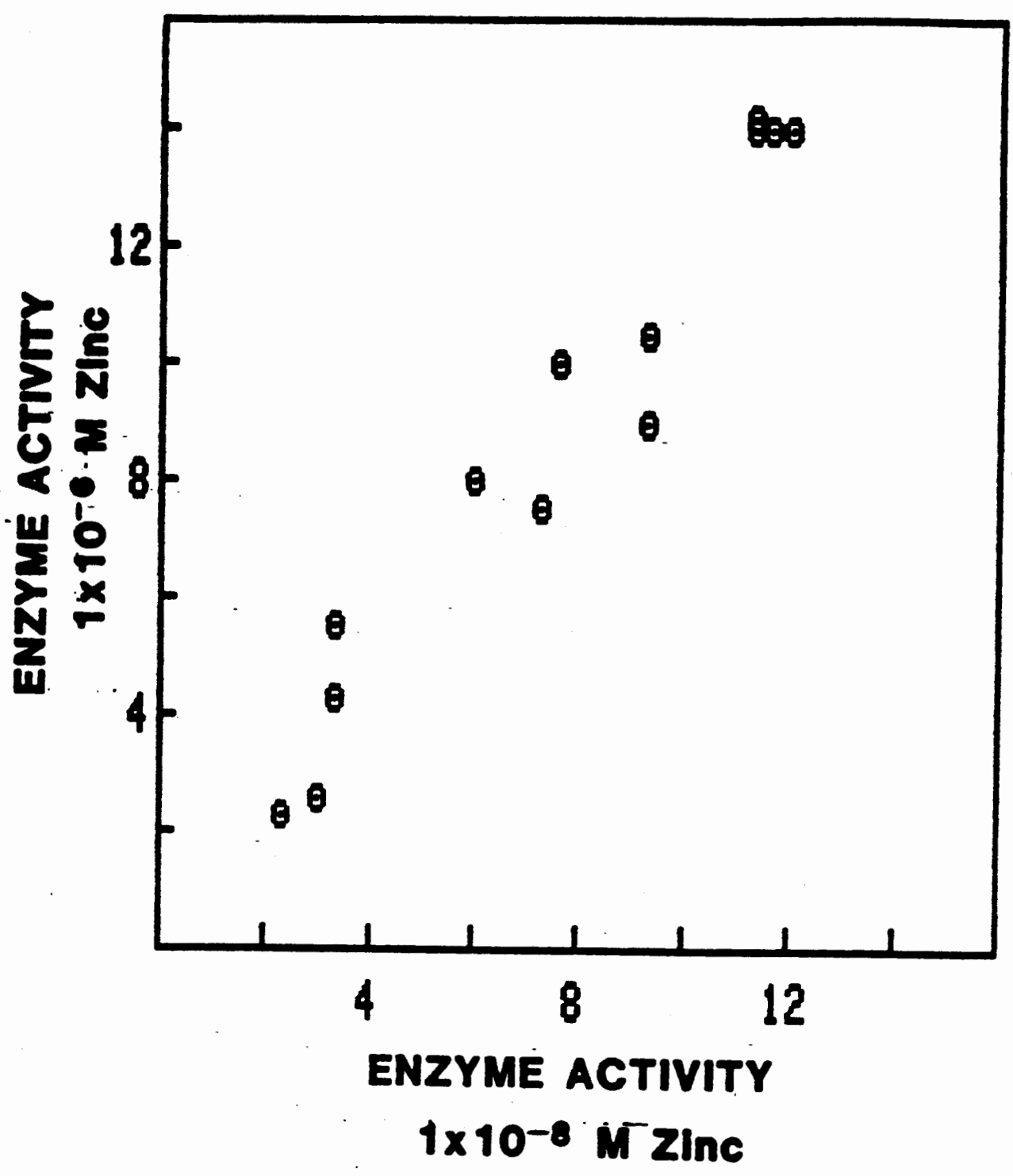

Elgux:-8. A comparison of alkaline phosphatase

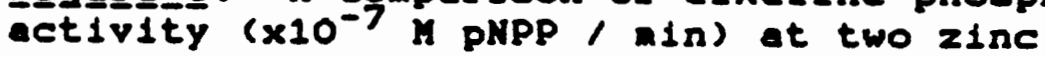
concentrations. 
concentration. If the questionable deta discussed in the firat paragraph of this section is ignored (activity of $10.6 \times 10^{-7} \mathrm{MNPP} / \min$ at $4 \times 10^{-5} \mathrm{M}$ coppers, the $\mathrm{r}^{2}$ value increases to 0.85 (Figure 6). The activity of alkaline phosphatase drops $10.4 \times 10^{-7} \mathrm{M}$ PNPP, min per one unit change in $\mathrm{pCu}$ ( $\mathrm{pCu}=5 \pm 0.5$ ).

The enzyme activity at varlous aluminum and copper concentratione was compared between two experiments with the same zinc concentration $\left(1 \times 10^{-8} \mathrm{M}\right)$ and two experinents with a $100 x$ difference in added zinc concentrations (Figure 8). At time zero, the relative activity of the enzyme exposed to copper was greater in the solution with higher zinc. The difference averaged about ten percent of the control rate. After twenty-four hours, the rate at all copper and aluminum concentrations was higher in the buffer with more zinc, but the relative inhibition caused by these metals was the same.

\section{SECTION 3}

\section{Zinc Chenistry}

The results obtained in section one and two suggested that the buffer solution used contained some zinc as a contaminant. Nitrilotriacetic acid (NTA), a component of the enzyme buffer, competes as a ligand with alkaline phosphatase for zinc (Cohen \& Wilson 1966). If the zinc ion concentration of a solution is low enough, NTA can 
TABLE VII

REACTIVATION OF ALKALINE PHOSPHATASE

AFTER ZINC ADDITION

\begin{tabular}{|c|c|c|c|c|c|}
\hline Time & Zinc & $\begin{array}{c}\text { Enzyme } \\
\text { Activity }\end{array}$ & $\begin{array}{l}+10 \text { min } \\
<-- \text { time }\end{array}$ & $\begin{array}{c}+1 \text { hour } \\
\text { after zinc }\end{array}$ & $\begin{array}{r}+4 \text { hours } \\
\text { addition- }->\end{array}$ \\
\hline 0 & $1 \times 10^{-8}$ & 17.9 &.-- &.-- &.-- \\
\hline 0 & $1 \times 10^{-7}$ & 17.9 &.-- &.-- &.-- \\
\hline $30 \min$ & $1 \times 10^{-8}$ & 3.9 & 11.6 & 12.3 & 13.3 \\
\hline $30 \mathrm{~min}$ & $1 \times 10^{-7}$ & 8.0 & 12.3 & 14.0 & 15.0 \\
\hline $6 \mathrm{hrs}$ & $1 \times 10^{-8}$ & 0.0 & 10.9 & 13.7 & 15.4 \\
\hline 6 hrs & $1 \times 10^{-7}$ & 4.2 & 9.5 & 11.2 & 14.0 \\
\hline 20 hrs & $1 \times 10^{-8}$ & 0.0 & 10.9 & 14.0 & 13.7 \\
\hline $20 \mathrm{hrs}$ & $1 \times 10^{-7}$ & 4.9 & 8.1 & 10.9 & 11.6 \\
\hline
\end{tabular}

activity $=\times 10^{-7} \mathrm{M}$ PNPP $/$ min 


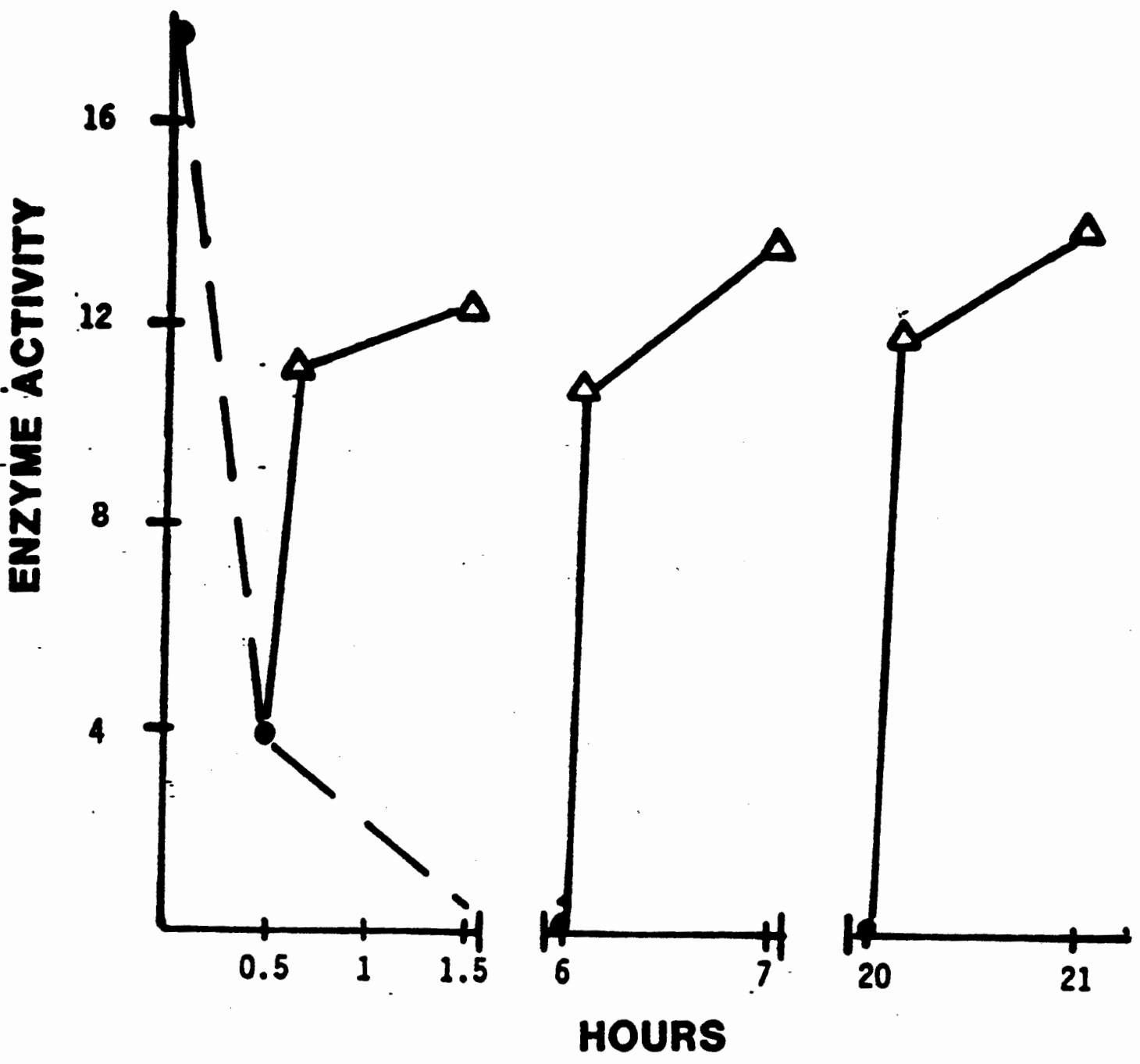

Figure_9. Alkaline phosphatase was exposed to a low zinc $\left(1 \times 10^{-8} \mathrm{M}\right)$ buffer. The activity decreased with time. At 30 minutes, 6 hours and 24 hours the concentration of 21 ne was increased to $1 \times 10^{-8} \mathrm{M}$ and the recovery of activity was monitored.

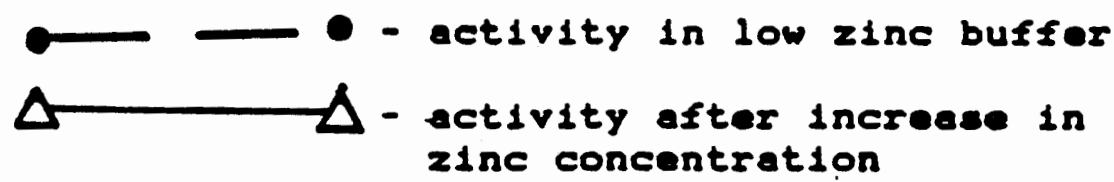


to $1 \times 10^{-6} \mathrm{M}$. The recovery of activity was determined atten minutes, one hour, and four hours after zinc addition (Elgure 9).

RESULTS

The use of chelex treated $\mathrm{Na}_{2} \mathrm{CO}_{3}$ did alter the characteristics of the buffer. It was necessary to add zinc to the solution to maintain alkaline phosphatase activity. With a zinc concentration of $2 \times 10^{-8} \mathrm{M}$, the enzyme activity dropped from $17.9 \times 10^{-7} \mathrm{M}$ pNPP, min at time zero to 3.9 $\times 10^{-7} M$ PNPP, min after thirty minutes. No activity was detected after $81 \times$ hours. In "non-chelexed" buffer, the activity was consistent for four days.

Reactivation of alkaline phosphatase could occur twenty hours after zinc was striped from the enzyme (Table VII). The activity of enzyme exposed to $1 \times 10^{-8}$ and 1 $\times 10^{-7} M z i n c$ would increase if the zinc concentration was raised to $1 \times 10^{-6}$ M (Figure 9). About seventy-five percent of the reactivation would occur within ten minutes of zinc addition. The activity continued to increase over four hours.

\section{DISCUSSION}

Tris is the recommended buffer for alkaline phosphatase assays because of its weak zinc binding strength. Although the activity was the greatest in Tris, a dependable equilibrium constant between the chelator and 
aluminum is not available. EDTA was not used because the activity of alkaline phosphatase could not be maintained in the presence of this chelator. EDTA may act to inhibit the enzyme by competing for the zinc ion.

The combination of $\mathrm{NaHCO}_{3}\left(1 \times 10^{-3} \mathrm{M}\right)$ and NTA $\left(1 \times 10^{-5}\right.$ M) was the buffer chosen for the metal toxicity studies. The $\mathrm{NaHCO}_{3}$ maintained $\mathrm{pH}(-7.7)$ and set the ionic strength. NTA functioned as the organic complexing agent. The equilibrium between NTA and the metals zinc, aluminum and copper were available (Smith and Martell 1975), making it possible to estimate chemical interactions and metal speciation.

This research is based on the observation that an increase in aluninum concentration leads to loss of aquatic organisms. My hypothesis is that the effect of the aluninum is due to its interaction with the metal chemistry of the systen. The results of this experiment indicate that the toxicity of aluninum is dependent on copper. In the absence of copper, the rate of alkaline phosphatase activity dropped 2.3 percent per $1 \times 10^{-5} \mathrm{M}$ rise in aluminum. The rate at $6 \times 10^{-5}$ aluminum was eighty-five percent of control after twenty-four hours. With copper present, the effect of increasing aluminum was sinilar to increasing copper. A copper concentration of $2 \times 10^{-5} \mathrm{M}$ magnified the effect of increasing aluminum by 400 percent (Figure 6). 
Alkaline phosphatase activity was found to relate to both the total copper concentration and cupric ion activity. This may be due to the high copper concentration required to inactivate the enzyme. If the concentration of metal is greater than the concentration of chelator, the free metal concentration is proportional to the total metal.

Rueter (1983) found alkaline phosphatase activity to relate only to the cupric ion. He also found the effective concentration to be much less (pCu $=10 \pm 2$ vs. $5 \pm 0.5$ ). Rueter performed his experiments in $1 \times 10^{-3} \mathrm{M}$ Tris. At that chelator concentration, the effects of total copper and the cupric ion could be separated since a greater change in total copper is necessary to change the activity of the cupric ion. Zinc contamination may be involved in the results obtained in each study (Rueter, pers. comm). The difference in results indicates the importance of the solution chemistry in trace metal studies.

An unexpected result was the apparent protective effect of aluminum at time zero. The activity level of the enzyme exposed to inhibitory levels of copper increased with aluminum concentration. This effect was no longer observed after two hours. A possible explanation is a kinetic effect. Both aluminum and copper can bind to a specific site on the enzyme. The binding of copper leads to inhibition while the binding of aluminum has little effect. At time zero, aluminum binding prevents copper 
inhibition. At higher aluminum concentrations more of the enzyme is protected. Over time copper can displace the aluminum from the enzyme so the effect is not observed at two hours.

Copper may inhibit alkaline phosphatase by displacing the native zinc (Foy et al 1978). The results of this experiment do not support or refute this hypothesis. The inhibition appears to occur in two steps. There is an initial inhibition which is evident in the time zero assays (Table VI). There is also an additional slow decrease in activity over time. Alkaline phosphatase contains 2 to 6 zinc tons per molecule (Coleman and Gettins, 1983). The affinities of the binding sites for the zinc vary. The initial inhibition may be due to copper displacing a weakly bound zinc or binding to another site on the enzyme. The slow continued inactivation may be caused by the interaction of the copper with a more tightly bound zinc ion. If the inhibition is caused by displacement, increasing the concentration of zinc should protect the enzyme by increasing the probability of zinc binding. The observation that increasing the zinc concentration leads to greater enzyme activity, but does not protect the enzyme from copper inactivation makes it hard to predict whether the inactivation is due to the displacement of the native metal. These results suggest that there is more $z$ inc in the buffer solution than expected. This is supported by the observation that the characteristics of the enzyme in the 
buffer changed after the solution was passed through a cation exchange column.

Cohen and wilson (1966) state that NTA will strip zinc from isolated alkaline phosphatase if the zinc concentration is low. In the chelex treated buffer, a zinc concentration of greater than $1 \times 10^{-6} \mathrm{M}$ is required to prevent NTA Inactivation. The inhibition caused by zinc removal can be reversed for at least twenty hours if the zinc concentration is increased. The reversibility of zinc binding to alkaline phosphatase allows zinc to be modeled as a co-factor of the enzyme (Chap $V$ ).

\section{CONCLUSION}

The effect of aluminum on alkaline phosphatase activity 1 s dependent on copper. In the presence of copper, an increase in aluminum concentration leads to enzyme inactivation. Aluminum alone has little effect. This supports the hypothesis that aquatic metal chemistry is important in determining the environmental effect of increasing aluminum.

The activity of the enzyme was related to both the total copper and cupric ion concentrations. The result varied from the prediction that free cupric ion activity was the most important chemical factor. This may be due to the experimental metal concentrations being greater than the chelator concentration. 
ALKALINE PHOSPATASE ACTIVITY IN SCENEDESMUS CULTURE: INTERACTIONS OF ALUMINUM AND COPPER

\section{INTRODUCTION}

This research has shown that the aquatic chemistry of aluminum and copper influences the growth rate of Scenedesmus quadricauda (Chapter II) and the activity of isolated bacterial alkaline phosphatase (Chapter III). In this chapter the effect of the metals on the activity of alkaline phosphatase from Scenedesmus is investigated. Algae synthesize alkaline phosphatase in response to phosphate limitation. The enzyme, a nonspecific phosphomonoesterase (Coleman and Gettina 1983), allows the cells to utilize dissolved organic phosphate (DOP) as a phosphorus source. Bacteria may be able to outcompete algae for the uptake of Inorganic phosphate, making DOP the primary source of phosphorus for phytoplankton (Currie and Kalft 1984).

Alkaline phosphatase is found associated with the cell membrane (Kuenzler and Perras 1965). External enzymes have advantages in trace metal studies (Rueter 1983). Alkaline phosphatase 1 exposed directly to the chemistry of the medium. Internal enzymes may be protected from metal toxicity by the large number of potential binding sites in the cytoplasm. 


\section{METHODS}

A modified version of Fraquil (Morel et al 1979) was prepared. The use of $1 \times 10^{-6}$ NTA in place of EDTA allows comparison between the chemical interactions in the growth nedium and the enzyme buffer solution (Chapter III). 3-phosphoglycerate(3PG) (1 $\left.\times 10^{-7} \mathrm{M}\right)$ was used as the sole phosphorus source to promote the synthesis of alkaline phosphatase. The medium was prepared in the manner described in the methods of the growth rate experiments (Chapter II), except the 3PG was added to the solution after it had been "chelexed".

The experimental aluminum concentrations were $0,0.5$, 1 and $2 \times 10^{-5} \mathrm{M}$. At each aluminum concentration, four copper concentrations were tested $\left(0,4,8,12 \times 10^{-6} \mathrm{M}\right)$. $700 \mathrm{~mL}$ cultures of Scenedesmus quadricaude (culture II, Freshwater Institute algal culture collection, Freshwater Institute, Winnipeg, Canada) were grown in acid washed one liter polycarbonate flasks. After the culture had grow for 5 to 8 days, a $200 \mathrm{ml}$ sample was removed and placed in a clean container. The $\mathrm{pH}$ was measured and recorded. AlCl3 (1)10-2 M) was added to bring the aluminum concentration to the experimental level. The $\mathrm{pH}$ was measured again. If a change had occurred, the $\mathrm{pH}$ was corrected with $0.1 \mathrm{M} \mathrm{NaOH}$. After 45 minute the $\mathrm{pH}$ was verified a final time. $10 \mathrm{ml}$ samplea of the culture were transferred to $30 \mathrm{ml}$ 
polycarbonate tubes. An hour after the addition of aluminum, copper $\left(2 \times 10^{-4} M \mathrm{CuSO}_{4}\right)$ was added to the tubes. The algae were exposed to the copper for an additional hour before the assays were performed. Replicate tubes of aluminum free cultures were assayed as a control.

Five tubes could be assayed at one time. The first 10 ml sanple was spiked with $0.2 \mathrm{ml}$ of $1 \times 10^{-3} \mathrm{M}$ pNPP. After gentle mixing, $3 \mathrm{ml}$ were filtered into a $1 \mathrm{~cm}$ path length spectrophotometer cuvette. The absorption at $410 \mathrm{~nm}$ was measured and recorded. This process was repeated for each of the five samples. After the initial reading of the fifth sample was recorded, a second round of measurements was begun. The exact time of each filtration was recorded. Approximately six minutes elapsed between repeated sampling of any single tube. After the absorption of each sanple had been measured three times, the enzyme activity was calculated.

Because the number of cella in a culture varied, the absolute enzyme activity of the control samples was not consistent between experiments. The effect of metal addition is reported compared to the enzyme activity the two control assays. As the exact rate differed on different days, the results are given as percent of control activity.

The chenical speciation for each concentration combination was estimated using a Pascal version of MICROQL (Westall et al 1976; Westall 1985). Due to a limited memory 
capacity, a condensed Fraquil data matrix was used (Table V). Components which where shown by MINIQL (Westall et al 1976) not to significantly affect metal speciation were excluded.

\section{RESULTS}

The observed effect of increasing aluminum changed as the concentration of copper increased (Figure 10). In a copper free culture, the addition of $2 \times 10^{-5} \mathrm{M}$ aluminum inhibited the activity of alkaline phosphatase by sixteen percent. This concentration of aluminum led to an activity decrease of 88 percent if the copper concentration was $8 \times 10^{-6}$ M (Table VIII).

The EC50 imetal concentration required to inhibit enzyme activity by 50 percent) for copper was determined by graphing the data (rate $v$. copper) and interpolating for copper concentration at 50x control activity (Figure 11). The copper EC50 decreased as the aluminum concentration was increased.

The activity of the enzyme in the presence of both metals was found to be related ( $\left.r^{2}=0.89\right)$ to the log cupric Ion concentration (Figure 12). The effective range of pCu 18 between 7.7 and 5.7 . In the absence of aluminum, there is not enough data to clearly state whether the cupric ion or total copper concentration controls toxicity. Enzyme activity did not relate to elther total aluminum or pal. 


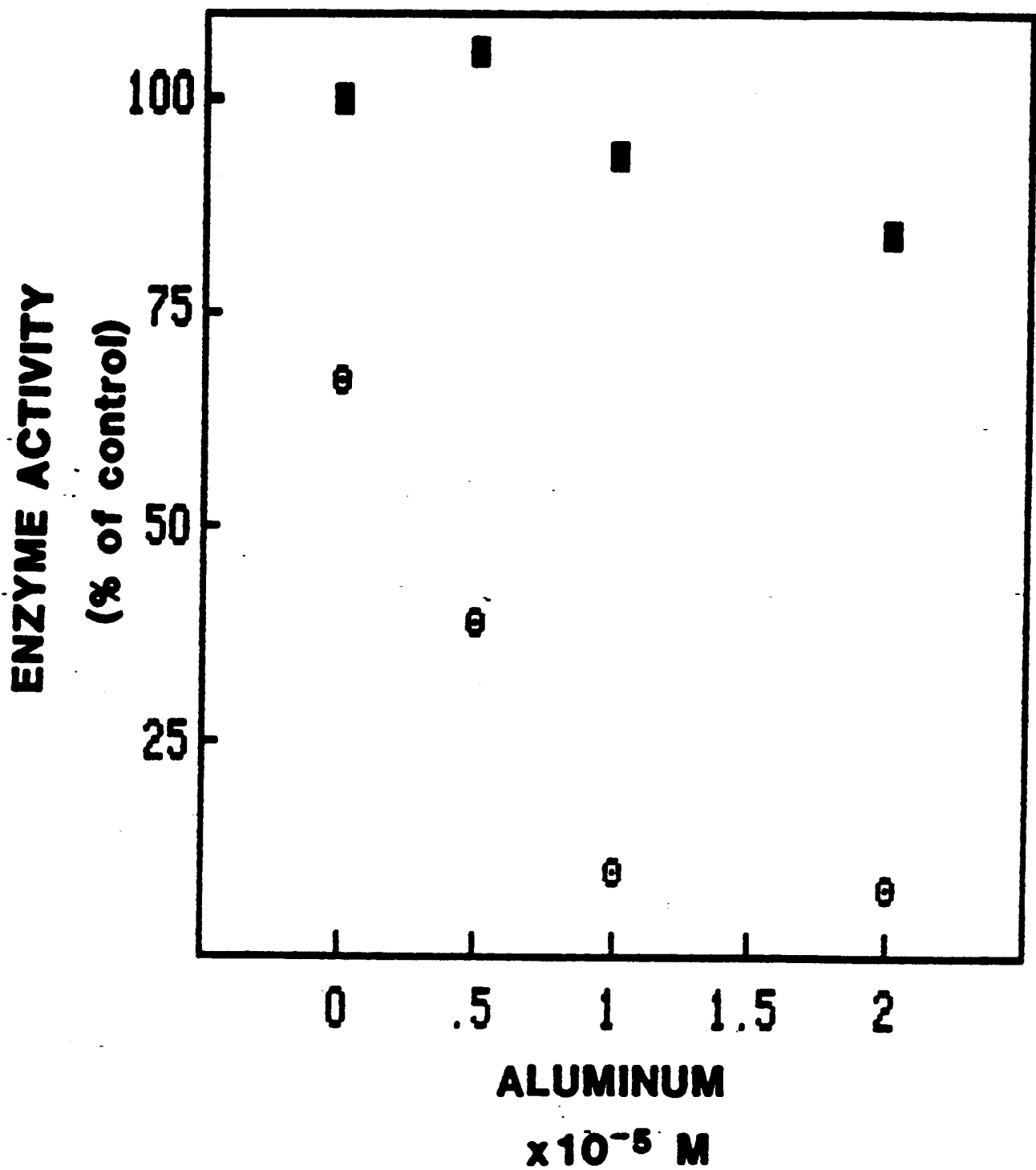

Elgure_10. The activity of Scenedesays alkaline phosphatase as a function of aluminum in the presence and absence of copper.

D. no copper

0 - $8 \times 10^{-6}$ a copper 
TABLE VIII

ACTIVITY OF SCENEDESMUS ALKALINE PHOSPHATASE (upper)

AND CUPRIC ION ACTIVITY (lower) AS A FUNCTION OF ALUMINUM AND COPPER CONCENTRATION

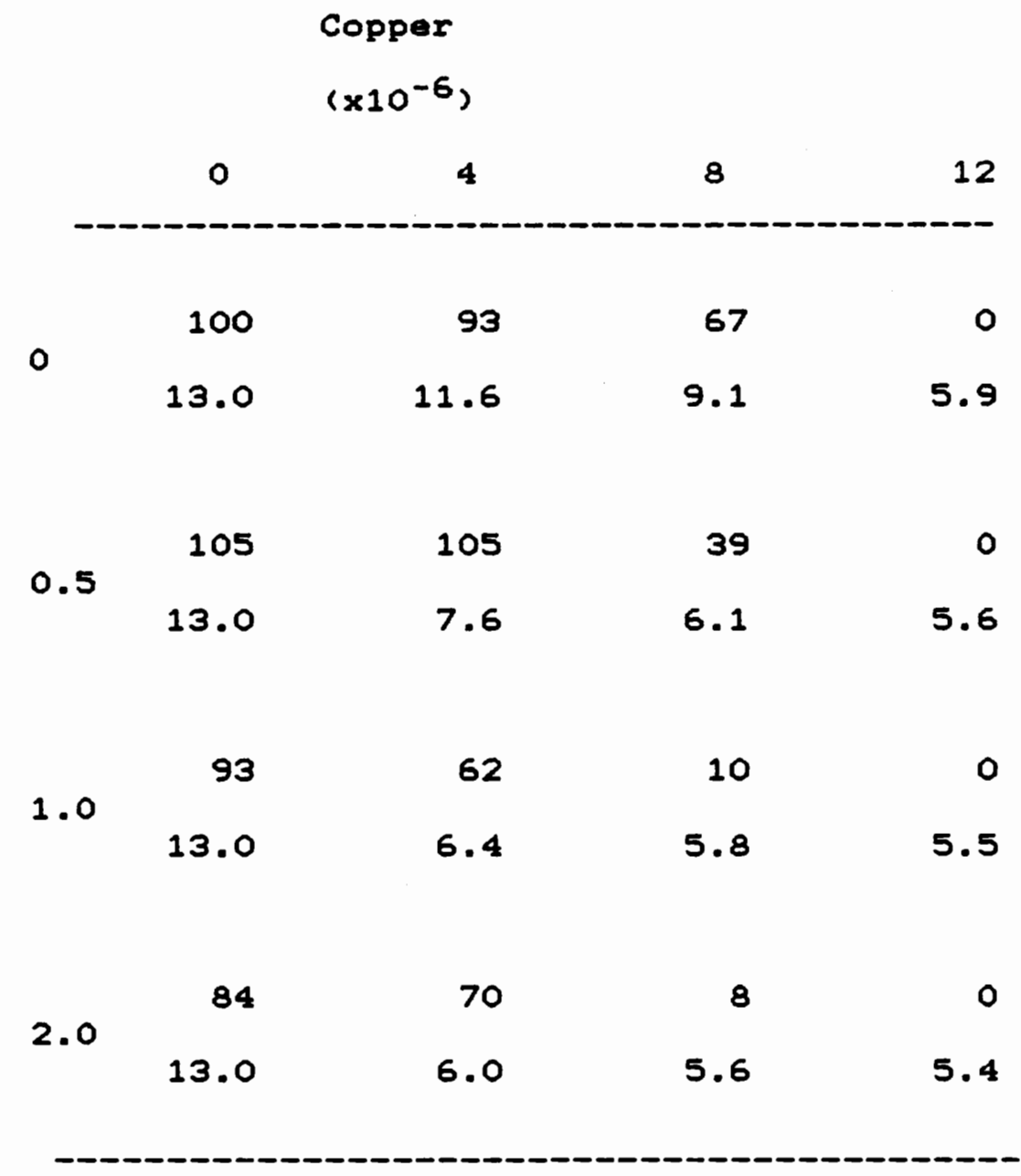

activity = percent of control 


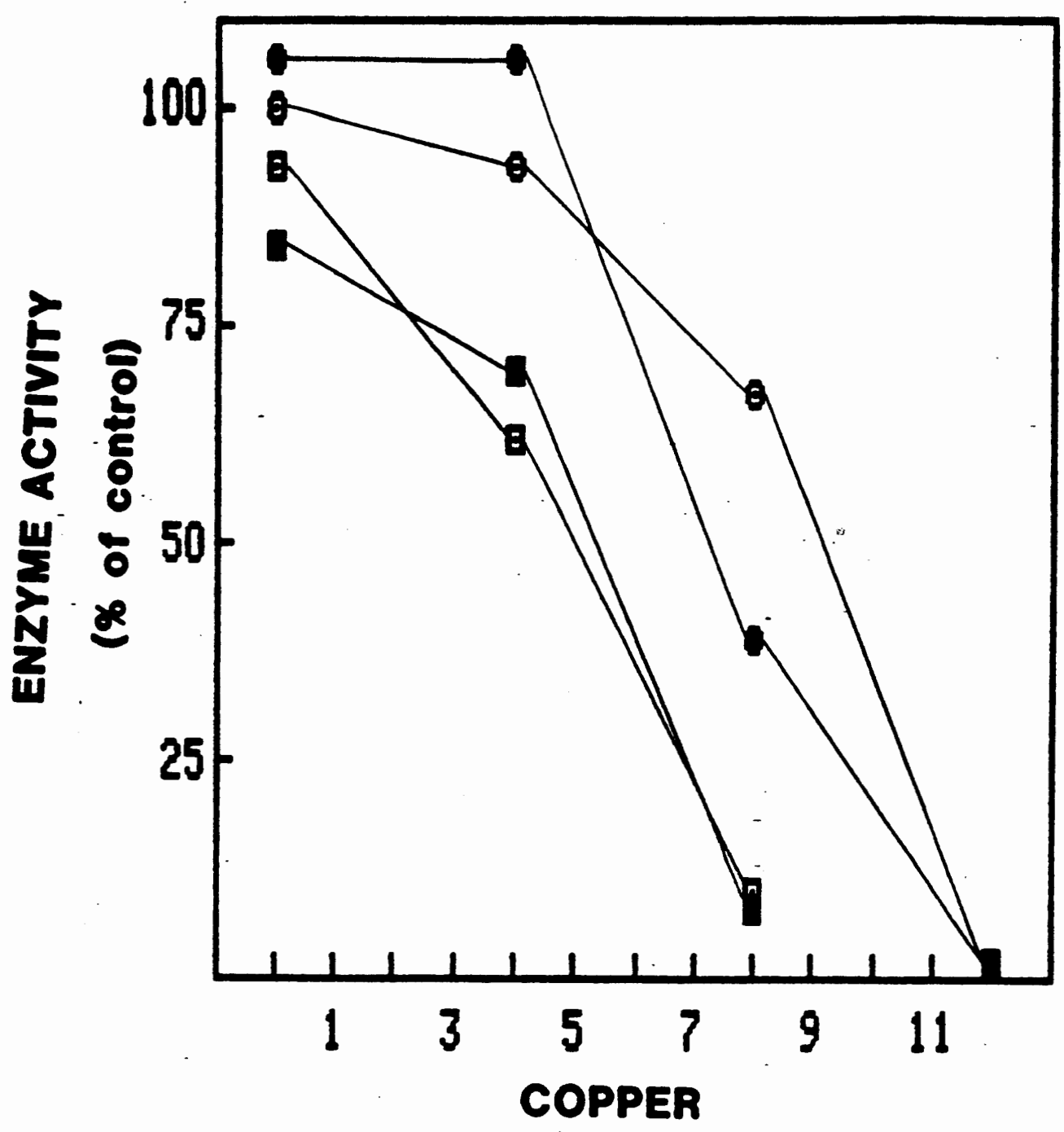

\section{$\times 10^{-6} M$}

Figure_11. The activity of Scenedegmus alkaline phosphatase as a function of copper concentration at four aluminum concentrationa.
- no eluainmum
0 - $5 \times 10^{-6} \mathrm{M}$ aluminum
E- $1 \times 10^{-5}$ aluminum
$-2 \times 10^{-5} \mathrm{M}$ aluminua 


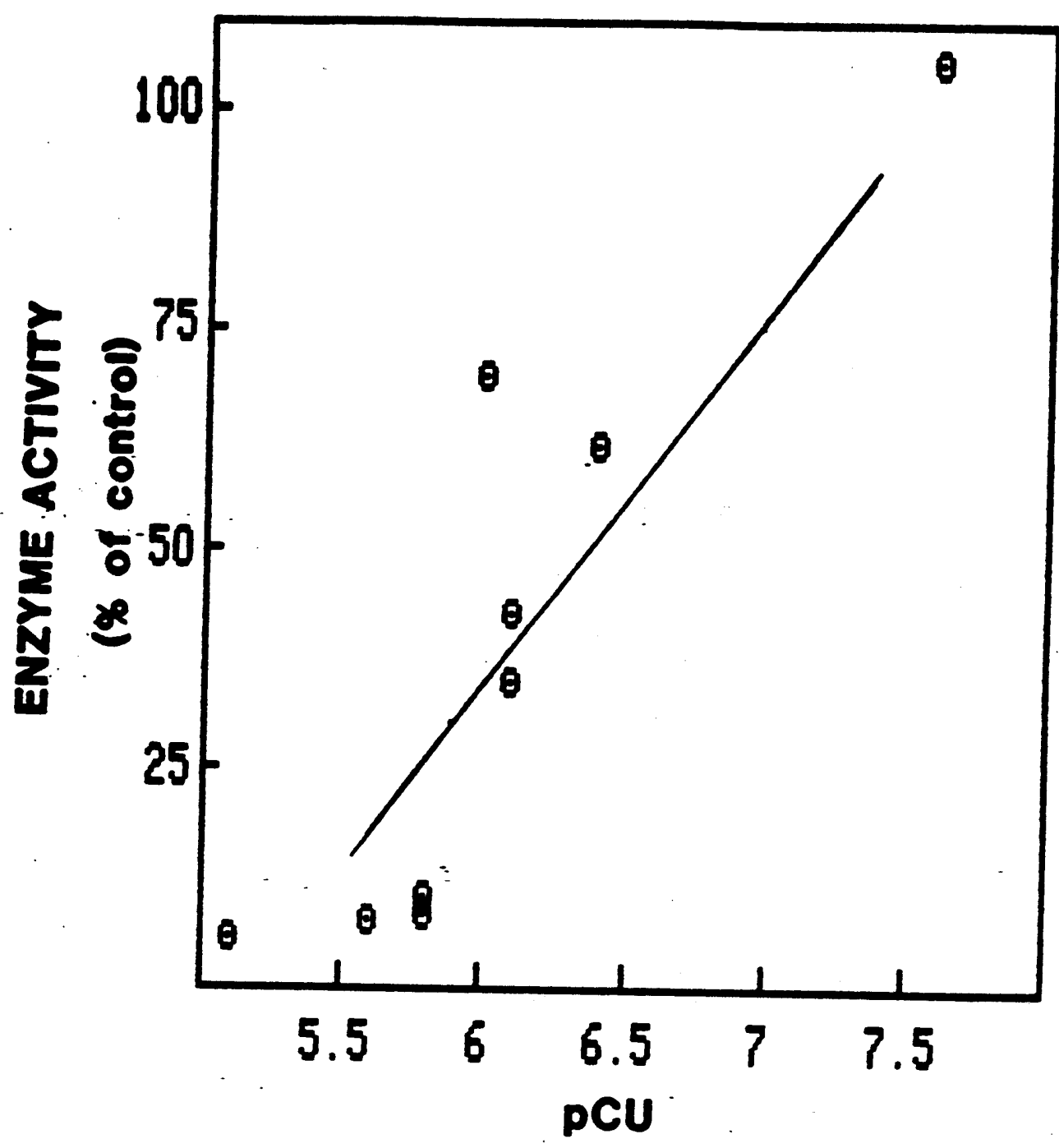

E19ue-12. The activity of Scengdesane alkaline phosphetese as a function of cupric lon activity. 


\section{DISCUSSION}

The concentration of copper was found to be important in determining aluminum toxicity. Aluminum alone had little effect on the activity of Scenedesmus alkaline phosphatase. In the presence of copper, increasing the concentration of aluminum led to a large decrease in activity.

The results support the hypothesis that chemical speciation is critical in determining metal toxicity. A strong correlation was found between enzyme activity and cupric ion concentration. The effect of aluminum concentration on the level of the cupric ion can be seen in Figure 13. At a set copper concentration, the level of the toxic copper species increases with aluminum concentration.

Although it has been shown that Scenedesmus alkaline phosphatase and the growth rate of the alga are both sensitive to cupric ion activity, I am not suggesting that the inhibition of the enzyme is the cause of growth rate inhibition. Alkaline phosphatase is acting as a model enzyme system. The decrease of growth may be due to the partial inhibition of many enzymes. The important point is that the effect of changes in metal speclation have been shown with an organism and with a single enzyme.

This experiment increases the number of alkaline phosphatase systems known to be sensitive to cupric ion 


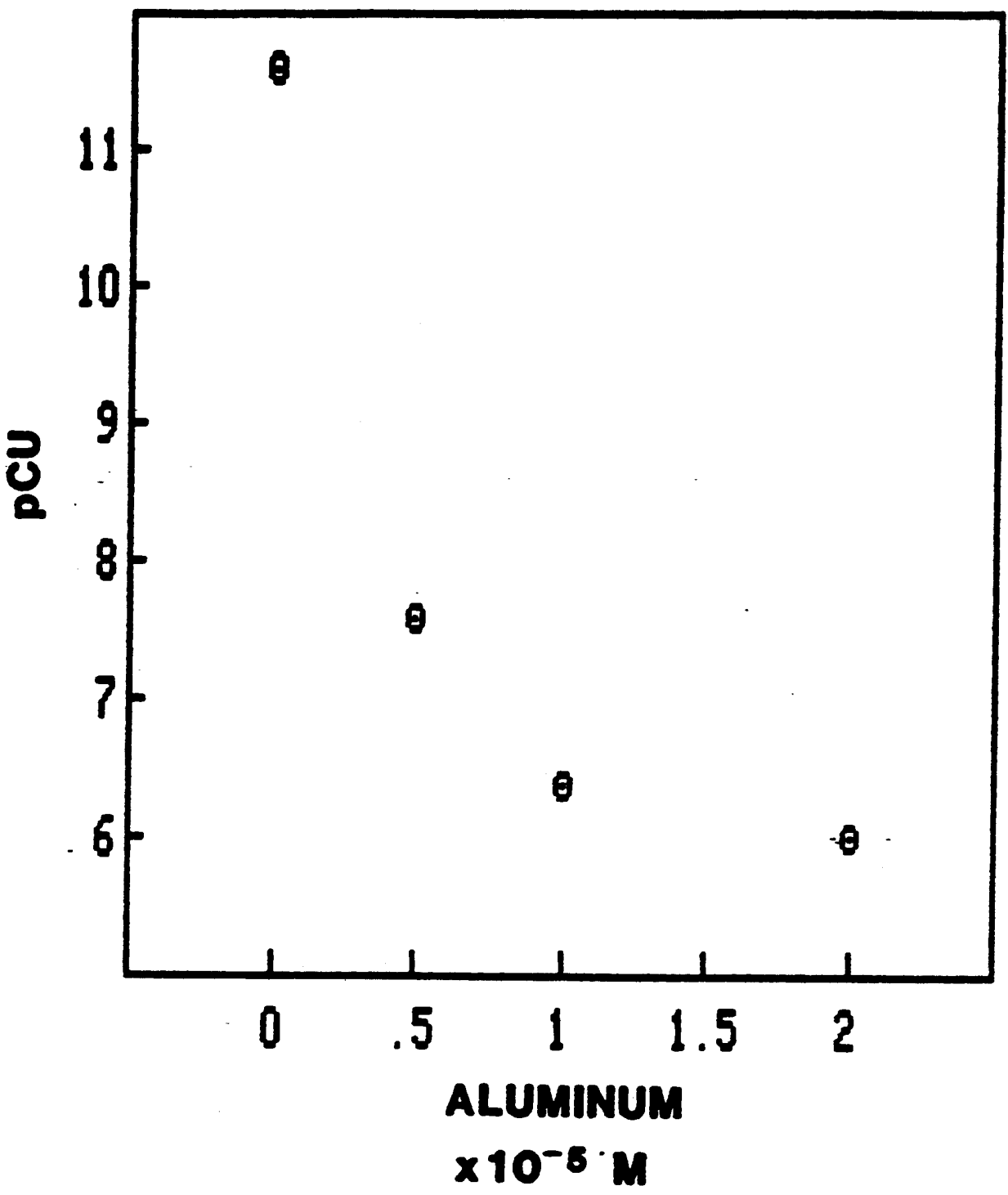

Elgurs-13. The activity of the cupric ion increases with aluminum concentration. The copper concentration 1. sent at $8 \times 10^{-6} \mathrm{M}$. 
activity. Rueter (1982) found the enzyme to be an effective biochemical marker of toxicity in three increasingly complex environments. Comparable results were obtained in studies with the isolated enzyme, cultures of marine diatoms, and natural assemblages of freshwater phytoplankton.

The bioassay developed in this research could be used to quickly estimate the effect of changing metal concentrations in natural waters. A concentrated culture of Scenedesmus could be added to a water sample. The activity of the enzyme would be monitored before and after the addition of netals. If a portable spectrophotometer (e.g. Hach Co.) is available, this work could be performed in the field.

It has been shown that enzymes exposed to the environment are sensitive to changes in the metal chemistry. Similar effect may occur in other organisms. The observed sensitivity of fish to increased aluminum (Cronan and Schofield 1979) may be because of the number of Important enzymes present in gill membranes.

\section{CONCLUSION}

The results obtained with Scenedesmus alkaline phosphatase were similar to those obtained with the isolated enzyme. In the presence of aluminum and copper, 
63

enzyme activity is significantly correlated with cupric ion activity.

Aluminum alone was shown to have little effect on the enzyme. If copper was present in the medium, enzyme activity decreased a the aluminum concentration increased. 


\section{CHAPTER $V$}

\section{THE USE OF A COMPUTER MODEL TO PREDICT THE INTERACTION OF COPPER AND ALRALINE PHOSPHATASE}

\section{INTRODUCTION}

This research has shown thet metal speciation determines the effect of copper on alkaline phosphatase activity. Copper and zinc lons compete for the netal binding site of the enzyme (Foy et al 1978). Alkaline phosphatase can be considered as a ligand with different affinities for transition metals. The goal of this section is to model the interactions between the enzyme, zinc and copper in a way to predict the results of perturbations in aquatic chemistry.

\section{THEORY}

In chapters II through IV, the computer progran MICROQL (Westall et al 1976) was used to model chemical interactions and estimate metal speciation. This chapter extends the use of MICROQL to model the actual interactions between alkaline phosphatase and the metals zinc and copper. This work is based on the assumption that the zinc binding site of the enzyme acts as a ligand. A knowledge of the outcome of competition between the metals for the binding site should allow one to predict the enzyme activity at at given metal concentration. 
The concentration of the alkaline phosphatase-zincpNPP (E-Z-P) complex should be the factor controlling the measured enzyme activity (Lehninger 1982). A conditional stability constant for E-Z-P will be determined. An accurate formation constant is required to estimate the complex concentration. The formation of the alkaline phosphatase-zinc-pNPP complex depends on the interaction of both $\mathrm{Zn}+2$ and PNPP with the enzyme. Kinetic experiments were performed in which the concentration of either zinc or pNPP was held constant at a saturating level, while the concentration of the other was varied. Using the Michaelis-Menten equation, the $K$ for for both the substrate and the metal was determined. $K$ is an indicator of the stability constant between an enzyme and another substance. If it is assumed that the binding of zinc and pNPP are sequential events:

$$
\begin{aligned}
& \text { 1. Enzyme + Zn } \quad<====>\text { Enz-Zn } \\
& \text { 2. Enz-Zn + PNPP }<====\text { E }-Z-P
\end{aligned}
$$

the stability constants of the tricomponent complex should be the product of the enzyme-zinc and enzyme-pNpp constants (Rueter, pers. comm.). In other words, the $\log K$ of the E2-P complex should be the sum of the $\log K$ of each substance determined experimentally.

The stability constant between alkaline phosphatase and copper was determined in the second part of the experiment. Copper is thought to inhibit alkaline 
phosphatase by displacing the zinc (Foy et al 1978). The two netals compete for the same site on the enzyme. An Initial aseunption was that the relative affinities of copper and zinc for the binding site should be similar to other organic ligands. Knowledge of the zinc stability constant should allow one to predict the copper constant by comparisons with tables of known values (Smith and Martell 1975). Although it was supported by the results, this asumption may not always be valid. With stability constants for copper and zinc, MICROQL could be used to predict the outcome of competition of metals for binding to alkaline phosphatase.

METHODS

The activity of alkaline phosphatase was assayed using the method described in Chapter III. The buffer ( $1 \times 10^{-3}$ $\mathrm{NaHCO}_{3}, 1 \times 10^{-5} \mathrm{NTA}$ ) used in determining the $\mathrm{Km}$ of pNPP contained $5 \times 10^{-6} \mathrm{ZnCl}$. Five aubstrate concentrations between $1.1 \times 10^{-6}$ and $4.4 \times 10^{-5} \mathrm{M}$ were tested (Table IX). In deternining the $K$ value for zinc, the pNPP concentration was maintained at $4.4 \times 10^{-5} \mathrm{M}$. The enzyme was exposed to low zinc for four hours to allow zinc equilibrium to be reached between the enzyme and NTA.

The chemical speciation for each zinc concentration was estimated using a Pascal version of MICROQL (Westall 1985). The progran was run on a Zenith 151 PC (Zenith data 
TABLE IX
A COMPARISON OF EXPERIMENTAL RESULTS
WITH THOSE PREDICTED BY MICROQL

$\begin{array}{ccccccc}\begin{array}{c}\text { Zn conc } \\ \times 10^{-7}\end{array} & \begin{array}{c}\text { experimental } \\ \text { enzyme } \\ \text { activity }\end{array} & \begin{array}{c}\text { predicted } \\ \text { enzyme } \\ \text { activity }\end{array} & \begin{array}{c}\text { experimental } \\ \text { percent } \\ \text { Vmax }\end{array} & \begin{array}{c}\text { predicted } \\ \text { percent } \\ \text { Vmax }\end{array} \\ 1 & 4.9 & 5.6 & 4.3 & 26 & 30 & 23 \\ 2 & 9.5 & 7.7 & 7.1 & 50 & 41 & 38 \\ 4 & 11.6 & 9.5 & 10.5 & 61 & 50 & 56 \\ 6 & 13.7 & 13.5 & 12.5 & 73 & 70 & 66 \\ 8 & 15.4 & 11.8 & 13.6 & 81 & 63 & 72 \\ 10 & 14.7 & 15.1 & 14.6 & 78 & 80 & 77 \\ 20 & 10.8 & 11.3 & 11.9 & 80 & 84 & 88\end{array}$

\begin{tabular}{|c|c|c|c|c|c|c|}
\hline $\begin{array}{l}\text { PNPP } \\
\text { conc. } \\
\times 10^{-6}\end{array}$ & \multicolumn{2}{|c|}{$\begin{array}{l}\text { experimental } \\
\text { enzyme } \\
\text { activity }\end{array}$} & $\begin{array}{c}\text { predicted } \\
\text { enzyme } \\
\text { activity }\end{array}$ & \multicolumn{2}{|c|}{$\begin{array}{c}\text { experimental } \\
\text { percent } \\
V \max \end{array}$} & $\begin{array}{l}\text { predicted } \\
\text { percent } \\
V_{\max }\end{array}$ \\
\hline 1.1 & 5.0 & 5.0 & 7.6 & 27 & 27 & 40 \\
\hline 2.2 & 9.8 & 10.5 & 10.8 & 52 & 56 & 58 \\
\hline 4.4 & 13.0 &.-- & 13.8 & 73 & -- & 73 \\
\hline 9.6 & 14.0 & 14.7 & 16.2 & 74 & 78 & 86 \\
\hline 44.0 & 18.2 &.-- & 16.9 & 96 & -- & 90 \\
\hline
\end{tabular}


systens). A matrix (Table V) was set up for the chemical components of the buffer. The stability constants used were obtained from MINEOL data files (Westall et al 1976). After the $K$ was determined for PNPP and $Z_{n}+2$, the matrix was expanded to include PNPP and alkaline phosphatase as components. In addition to the enzyme-zinc-pNPp complex, another species created by matrix expansion was enzyme-H. It was assumed that proton binding to the enzyme is similar to NTA (see page 67) so the NTA-H formation constant was used.

The procedure for testing various formation constants of the E-Z-P complex was to set the pNPP concentration at $4.4 \times 10^{-5}$ and the 21 nc concentration at $3.5 \times 10^{-7}$. Since these component concentrations gave an enzyme activity of one half Vmax, the E-Z-P complex should be 50 percent of the total enzyme present. The calculated - log $K$ for PNPP was 5.75 while 1 t was 11 for $\mathrm{Zn}^{+2}$, so the sun 16.75 was the firat log formation constant tried for the E-Z-P complex. The E-Z-P to total enzyme ratio was determined for $K$ values between 15.75 and 18.50 . At $p K=17.85$, the program estinated a ratio of 0.53 . As this compared favorably with experimental ratio of 0.50 , a computer titration of $z i n c$ was performed. At each zinc concentration, the percent enzyme saturation was compared to the percent Vmax determined experimentally. The zinc concentration was then set at $5 \times 10^{-6}$ zinc and a computer titration of pNPP was 
performed. Again the estimated enzyme saturation was compared to experimental results.

The experimentally determined binding constant between $2 n+2$ and alkaline phosphatase ( $p K=11$ ) was sinilar to the standard constant between $2 n+2$ and $N T A$ ( $p K=10.66$, Smith and Martell 1975). This suggests the metal binding site of the enzyme may be similar to NTA. This information was used to predict that the binding copper to the enzyme should have a stability similar to Cu-NTA (pK = 12.94 , Smith and Martell 1975). The MICROQL matrix was expanded to include the species Cu-enzyme. A computer titration was performed to predict the effect of increasing copper on the concentration of E-Z-P. The results were compared to enzyme activity deternined experimentally. Six copper concentrations between $2 \times 10^{-5}$ and $1 \times 10^{-4} \mathrm{M}$ were tested (Table $X$ ). The zinc concentration was maintained at 2 $\times 10^{-6} \mathrm{M}$, and the PNPP concentration uaed was $4.4 \times 10^{-5} \mathrm{M}$. The data were also used to get an improved estimate of the Cu-enzyme binding constant. The experimental conditions which gave an activity of fifty percent of Vmax were set in the computer. The $K$ was varied slightly and an estimation of enzyme saturation was calculated until an enzyme saturation of fifty percent was obtained. 
TABLE $X$

\section{A COMPARISON OF EXPERIMENTAL RESULTS WITH THOSE PREDICTED BY MICROQL}

\begin{tabular}{|c|c|c|c|c|c|c|}
\hline $\begin{array}{l}\text { copper } \\
\text { conc. } \\
\times 10^{-5}\end{array}$ & \multicolumn{2}{|c|}{$\begin{array}{l}\text { experimental } \\
\text { enzyme } \\
\text { activity }\end{array}$} & $\begin{array}{c}\text { predicted } \\
\text { enzyme } \\
\text { activity }\end{array}$ & \multicolumn{2}{|c|}{$\begin{array}{l}\text { experimental } \\
\text { percent } \\
\text { Vmax }\end{array}$} & $\begin{array}{c}\text { predicte } \\
\text { percent } \\
\text { Vmax }\end{array}$ \\
\hline 1 & 17.2 & 17.2 & 18.0 & 92 & 91 & 95 \\
\hline 2 & 13.8 & 16.6 & 10.6 & 73 & 86 & 56 \\
\hline 4 & 7.4 & 4.9 & 5.5 & 39 & 26 & 29 \\
\hline 5 & 7.1 & 5.7 & 4.5 & 38 & 30 & 24 \\
\hline 6 & 1.4 & 2.5 & 3.8 & 6 & 13 & 20 \\
\hline 8 & 1.0 & 2.1 & 2.8 & 5 & 11 & 15 \\
\hline 10 & 1.1 & 0.7 & 2.3 & 6 & 4 & 12 \\
\hline
\end{tabular}

Enz-Cu pK $=12.72$

$\begin{array}{lrrrrrr}1 & 17.2 & 17.2 & 18.3 & 92 & 91 & 97 \\ 2 & 13.8 & 16.6 & 12.9 & 73 & 86 & 68 \\ 4 & 7.4 & 4.9 & 7.6 & 39 & 26 & 40 \\ 5 & 7.1 & 5.7 & 6.3 & 38 & 30 & 33 \\ 6 & 1.4 & 2.5 & 5.4 & 6 & 13 & 29 \\ 8 & 1.0 & 2.1 & 4.2 & 5 & 11 & 22 \\ 10 & 1.1 & 0.7 & 3.3 & 6 & 4 & 18\end{array}$




\section{RESULTS}

The $\mathrm{Km}$ of pNPp in the experimental buffer was $1.9 \times 10^{-6}$ $M(p K=5.75)$. The $p K$ of $2 n+2$ was 11. The first pk tested, 16.75, gave eatimated enzymeE-z-P: enzymetotal ratio of 0.21 . Lowering the pK decreased the relative concentration of the complexed enzyme, while increasing the pK had the reverae effect. At the experimental conditions that gave an activity of one half Vmax, a pk of 17.85 led to an estimation of enzyme saturation of 0.53 . Table IX and Figure 14 show the comparison of the experimental results with the calculated activities. A lineer regression shows a relationship of 0.96 between the experimental results and the results of the simulated zinc titration. The relationship was 0.97 for the pNPP experiments.

The predicted resulta of copper addition and experimentally determined enzyme activities are presented in Table X. The Cu-NTA stability constant (pK = 12.96) is a good initial estimation for the interaction between copper and alkaline phosphatase. The model accurately predicts the effective range of copper concentrations. Copper concentrations below $1 \times 10^{-5} \mathrm{M}$ decreased the activity of the enzyme by less then ten percent (Table X). Alkaline phosphatase activity is inhibited if the level of copper increases further. The exact enzyme activity at a particular copper concentration was not accurately predicted. The model suggested lower activity at low copper levels C \& $5 \times 10^{-5} \mathrm{M}$ 


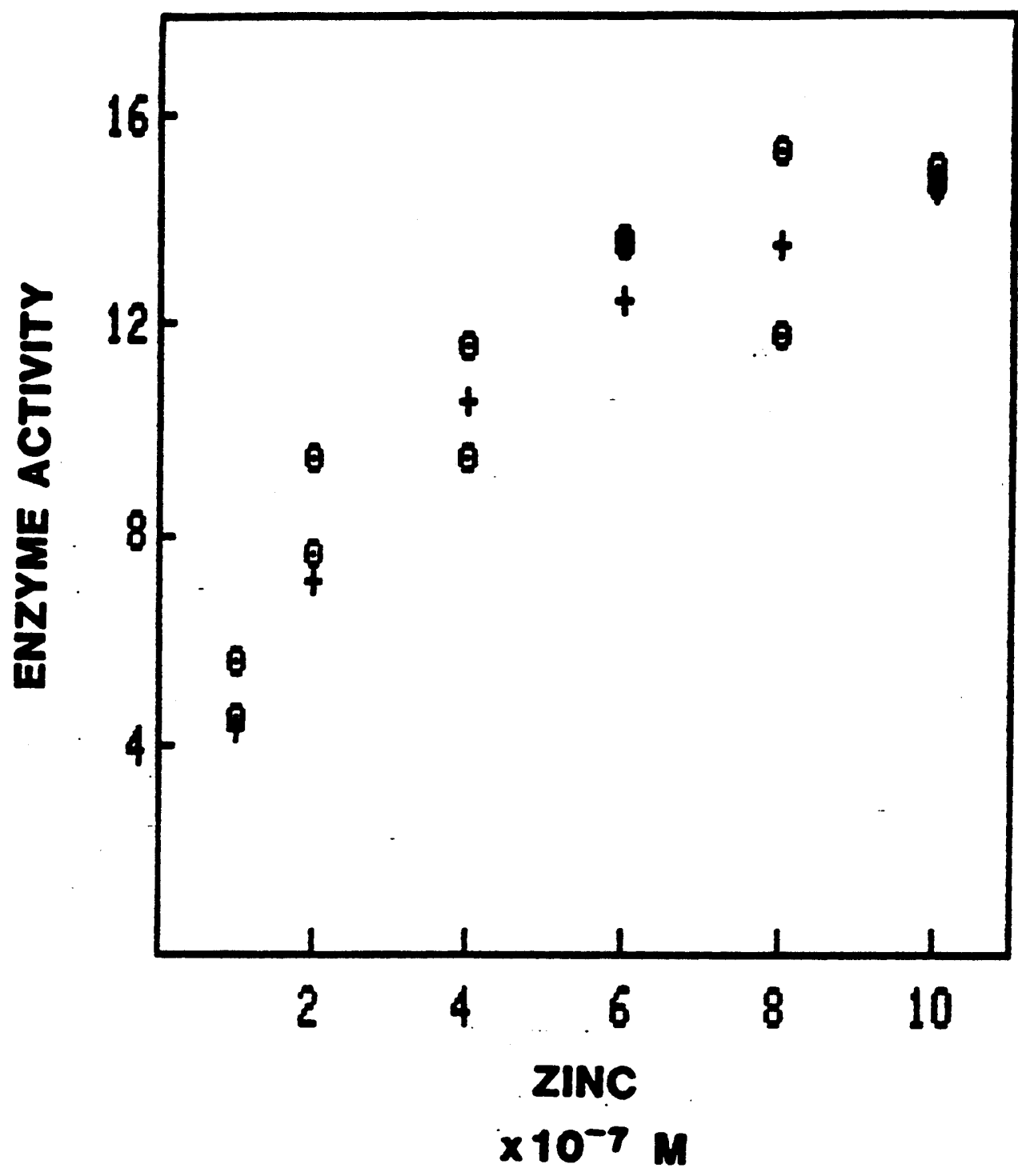

Eigure-14. A comparison of experimental and predicted alkaline phosphetase activity $\left(\times 10^{-7}\right.$ M PNPP, min) at ix zinc concentrations.

$\theta$ - experimentel

t - predicted 


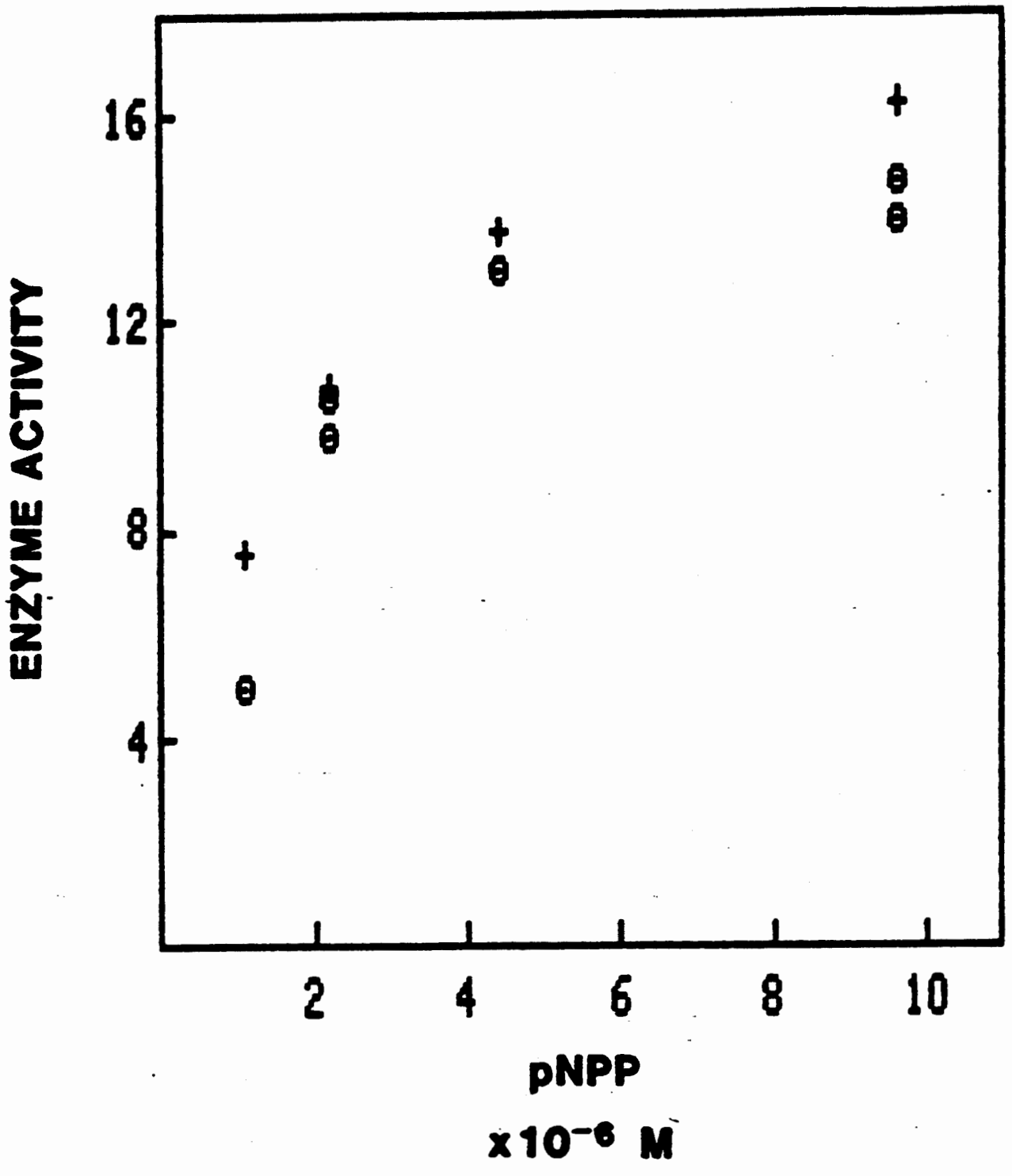

E1gure_15. A comparison of experingntal and predicted aikaline phosphatase ectivity $\left(\times 10^{-7}\right.$ I pNPP, min) at four PNPP concentrations.

0. - experimental

t - predicted 
copper) and greater enzyme activities at higher copper concentrations.

If the $\mathrm{pK}=12.72$, the model predicts fifty percent enzyme activity at the experimental copper EC50 ( $3 \times 10^{-5}$ M). The results of the computer titration using this value are in Table $X$. The predicted activities are closer to the experimental results for the samples with s $5 \times 10^{-5} \mathrm{M}$ copper. The model st111 underestimates the effect of higher copper concentrations (Figure 16)..

\section{DISCUSSION}

MICROOL can be used to predict the effect of substrate and zinc concentration on the activity of alkaline phosphatase. The assumption that the stability constant of the enzyme-zinc-pNPP complex is a function of the zincenzyme and pNPP constants was supported. The difference between the sum of the pKs for zinc and PNPP (16.75) and the value which accurately predicted experimental results (17.85) differed by only six percent. The success of the model suggest that the binding of zinc is a reversible process. This idea $1 \mathrm{~s}$ also supported by earlier resulta (Figure 9, Chapter III).

This model can be used to predict the effective range of cupric ion activity. Inhibition is the result of competition between zinc and copper for the metal binding site of alkaline phosphatase. MICROQL is effective in 


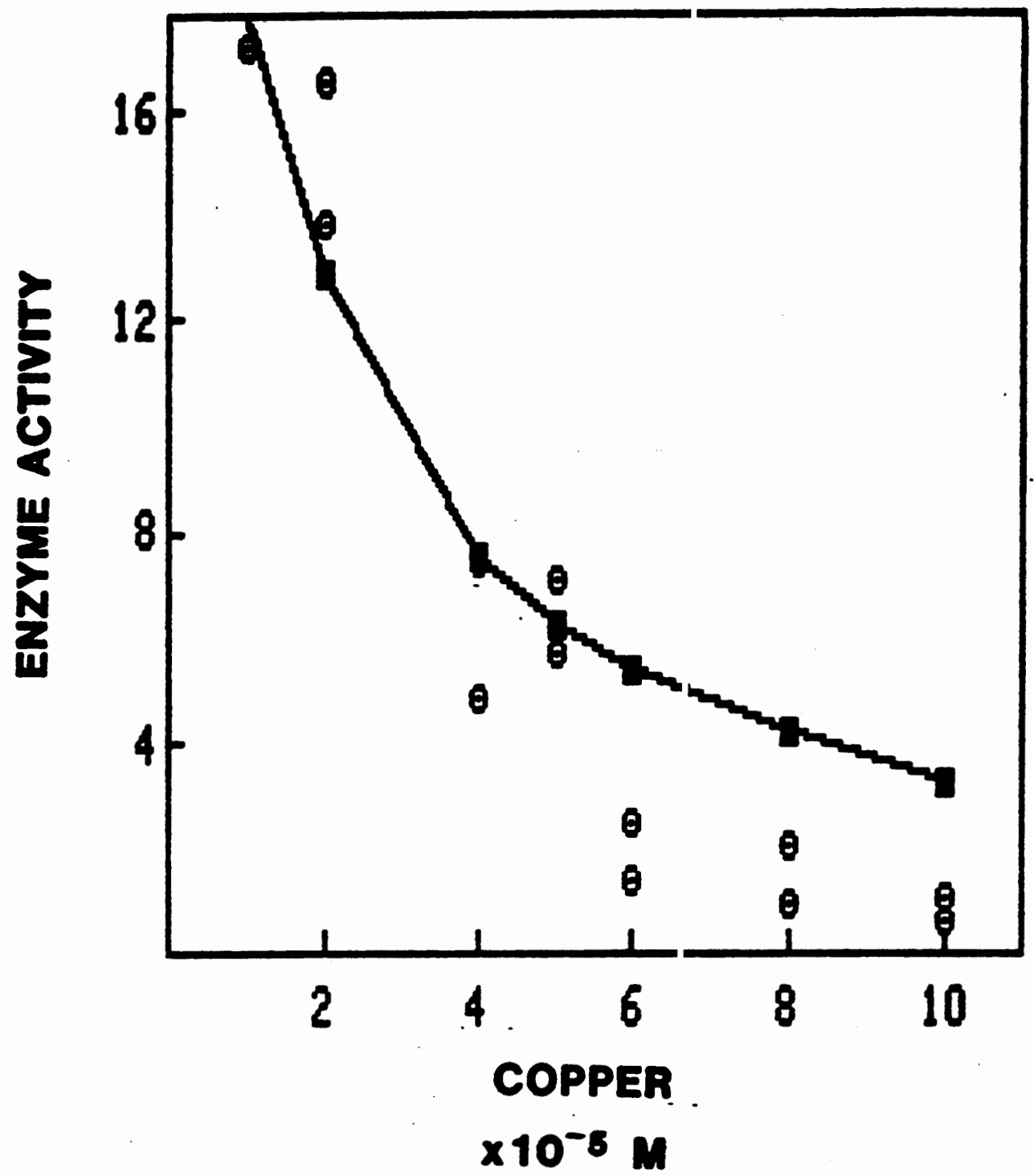

Eigure-16. A comparison of experimental and predicted alkaline phoophatase activity $\left(\times 10^{-7}\right.$ M PNPP, ain) at seven copper concentrations.

G - experimental

- predicted

non-competitive inisibitor curve 
estimating the outcome of metal-metal interaction if the stability constants between the components are known. This research has shown that satisfactory results are obtained if experimentally determined constants are used.

Predicted anzyme activity is greater than actual activity at high ( $5 \times 10^{-5} \mathrm{M}$ ) copper concentrations. Figure 15 is a graph of activity as a function of copper concentration. A comparison of the predicted results with theoretical enzyme inhibition equations (Lehninger 1982) indicates the model assumes copper acts as a noncompetitive inhibitor. The requirements of a noncompetitive inhibitor are that its binding to the enzyme prevents product formation, it does not bind to the active site, and finally the inhibitor binde reversibly with the enzyme. MICROQL also assumes that all reactions are reversible. Although the formation of the copper-enzyme complex may be chemically reveraible, inhibition has not been shown to be a reversible process.

The metal binding site of alkaline phosphatase has ligand characteristics similar to Nitrilotriacetic acid (NTA). The NTA-Me pK is 10.66 for zinc and 12.92 for copper (Smith and Martell 1975). The experimentally determined enz-Me pKs are 11 and 12.72 respectively. The structure of NTA is three acetic acids bound to a single nitrogen atom. The carboxyl groups are involved in metal complexation. This suggests the carboxyl groups of the 
anino acids glutamic acid and/or aspartic acid are likely to be involved in the metal binding site of alkaline phosphatase.

\section{CONCLUSION}

This investigation used the computer program MICROQL to model the interactions between alkaline phosphatase and the metals zinc and copper. The goal ts to be able to predict the effect of perturbations in the aquatic chemistry.

Experimental data and the computer program were used to determine the conditional stability of alkaline phosphatase with zinc, PNPP, and copper. The program accurately predicts enzyme activity at a given concentration of the substrate or native metal. The model also predicts the inhibitory range of cupric ion activity. The exact enzyme activity at a given copper concentration could not be predicted since the model assumes inhibition by copper to be reversible.

The conditional ablilty constants determined for alkaline phosphatase are similar to the known values for NTA. This auggeats the metal binding alte of the enzyme is similar to the chelator. 


\section{CHAPTER VI}

CONCLUSION

The goal of this research was to determine how the chemical interaction between aluminum and copper effects the green alga Scenedesmus guadricauda. The hypothesis was that the growth rate of the alga and the activity of its enzymes should be related to the concentration of the free cupric ion. In the presence of both metals, increasing the aluminum concentration can lead to copper toxicity. The results support this hypothesis.

A correlation $\left(r^{2}=0.87\right)$ was obtained between the growth rate of Scenedesmus and cupric ion activity.

Similar correlations were obtained between the cupric ion and the activity of bacterial $\left(x^{2}=0.85\right)$ and Scenedesmus $\left(r^{2}=0.89\right)$ alkaline phosphatase. Correlations were not found between any other chemical species and the growth rate or activity of the Scenedesmus enzyme. The bacterial alkaline phosphatase was also correlated to the total copper concentration ( $\left.r^{2}=0.88\right)$.

It was found that the computer program MICROQL (Westall et al 1976) can be used to model interactions of enzymes and metals in aqueous solutions. This aupports the hypothesis that enzymes act a ligands. The model requires the determination of conditional atability constants between the enzyme and the metals. One can predict the effect of changing metal concentrations on enzyme activity. 
An unexpected result was the apparent protective effect of low aluminum concentrations. The growth rate and enzyme activity were greater at a given cupric ion concentration if some aluminum was present (F1gure 2, Table VI). This may have either a chemical or biological explanation. MICROQL may not accuratly predict the interactions of dilute aluminum solutions. The apparent protective effect may actually be the comparison of the blological parameters to an overestimation of the cupric ion activity. It is also possible that aluminum does protect from copper inhibition. As discussed in Chapter III, aluminum ion may bind to sensitive sites on enzymes. This binding does not inactivate the enzyme, but delays or prevents copper from binding.

This research has shown that aluminum exerts a toxic response by influencing the metal speciation of a systen. In terms of applying the results to environmental problems, this observation is more important then the actual effect on Scenedesmus. As the concentration of aluminum is likely to increase in lakes affected by acid rain, an understanding of the nature of toxicity is required for optimal nanagement of the problem. This thesis has preaented a mechanism of toxicity that has not been discussed in the literature.

The effect of acid rain on algee is not of much concern (Dilion et al 1984). Scenedeamus was chosen as a 
test organism because of the ease of maintaining a chemically defined medium. The proposed mechanism should now be tested in more complicated systems. A study with zooplankton could determine if the effect of metal speciation is similar between plants and animals. The most important organisma affected by acid rain are fish. Although maintaining a chemically defined medium is difficult, a similar study with fish could be directly applied in the environment.

The results of this research suggest the type of lake that may be sensitive to increased aluminum. If changes in speciation are to ba significant, the concentration of a toxic metal must be high relative to the number of complexation sites or ligands available. A lake that is low in dissolved organic material but with a high concentration of copper or other toxic metal would be susceptible to changes in aluminum concentration. Field studies in such a lake could be done with sone of the techniques used in this research. Possible experiments include studies in which the metal concentration is varied in individual enclosures in lakes. This would allow the testing of the effect of metal interactions on natural populations. The use of alkaline phosphatase assays could be used to quickly estimate the interaction between the environmental chemistry and biochenistry in natural water samples. 
SUMMARY

This reseerch wes performed because of the increase in aluminum in lakes impacted by acid rain. The result suggests that aluminum can exert its effect by interacting with the aquatic chemistry of the system. Aluminum alone was found to have little effect in all the systems investigated. But in the presence of copper, increasing aluminum concentration had a large effect. In these experiments, aluminum displaced copper lons from the chelators present in solution. The copper ion is the actual toxic agent. Of course, copper ts not responsible for the loss of organisms in all lakes affected by acid rain. The exact toxic agent would depend on the relative concentration of all metals in a particular body of water. The important point is that the overall metal chemistry must be taken into account before a direct cause and effect between an increase in aluminum and toxicity can be establ1shed. 
APPENDIX A

COPPER AND LACTATE DEHYDROGENASE:

INHIBITION OF AN INTERNAL ENZYME

\section{INTRODUCTION}

An internal enzyme should show different sensitivity to metal toxicity than a enzyme exposed to the environment. Due to charged or polar nature of many organic molecules, the cytoplasm has numerous potential metal binding sites. The binding of metals to "safe" or unaffected sites decreases the free metal ion activity. A greater total metal concentration may be required to inhibit an internal enzyme. The time frame of metal inhibition is different for an internal and external enzyme (Rothatein 1959). External enzymes are immediately exposed to the changes in the chemistry of the anvironment. A metel must diffuse or be taken up into a cell before it can affect an internal enzyme.

My goal was to study the effecta of aluminum and copper on an internal enzyme and compared the results to those obtained for alkaline phosphatase. I chose to try lactate dehydrogenase ( $L D H)$ because it is a zinc metalloenzyme (Ochlal 1977) that should be present in algal cells. Unfortunately, a method could not be found that would allow for the extraction of the enzyme while maintaining defined conditions suitable for trace metal studies. This appendix 
discuseses the work that was performed with lsoleted LDH and describes the extraction techniques attempted.

\section{METHODS}

Isolated LDH Experiments- The enzyme lactate dehydrogenase (LDH) catalyzes the reaction:

$$
\text { pyruvate + NADH }<=====>\text { lactate + NAD }
$$

LDH activity is measured by following the disappearance of NADH in a spectrophotometer at $340 \mathrm{~nm}$.

The first goal was to determine the $V_{\text {max, }} K$, and enzyme saturation concentration. Lactate dehydrogenase (Sigma Co), was diluted to 1.5 units per milliliters in $1 \times 10^{-1} \mathrm{M}$ Tris. Six concentrations of pyruvate (Sigma Co) were teated, $2.8 \times 10^{-6}, 5.5 \times 10^{-6}, 1.1 \times 10^{-5}, 2.1 \times 10^{-5}$, and 3 $\times 10^{-5} \mathrm{M}$. Two milliliters of a $1 \times 10^{-1} \mathrm{M}$ Tris solution was added to a cuvette. To begin each assay, $0.1 \mathrm{ml}$ of the LDH-Tris solution was added to the cuvette. The absorption of each sample was recorded every two minutes for ten minutes. This experiment was repeated using a $1 \times 10^{-3} \mathrm{M}$ buffer.

The effect of three concentrations of copper was determined. Copper $\left(5 \times 10^{-2} \mathrm{M} \text { CuSO4}\right)^{2}$ was added to $20 \mathrm{ml}$ samples of $1 \times 10^{-1}$ Tris to bring the final concentration to $2.5 \times 10^{-4}, 2.5 \times 10^{-5}$, and $2.5 \times 10^{-6} \mathrm{M}$. Two mi11111ters of the LDH-Tris solution described above was added to each sample. Two milliliter subsamples were used in the enzyme 
assays. $0.25 \mathrm{ml}$ of the pyruvate and $0.25 \mathrm{ml}$ of NADH were added to the cuvettes to begin the assays. The activity of the LDH was determined at time zero, 2 hours, 8 hours and 24 hours.

The effect of copper in a solution of $1 \times 10^{-3}$ Tris was then investigated. Six concentration of copper between 1 $\times 10^{-8}$ and $1 \times 10^{-3} \mathrm{M}$ as well as a copper free control were tested. For each experimental concentration, $5 \times 10^{-2} \mathrm{M}$ $\mathrm{CuSO}_{4}$ was added to ten milliliters of the Tris buffer. Twelve units of LDH was added to each sample. Assays were performed in $1 \times 10^{-1}$ M Tris. A similar experiment was run testing the effects of four aluminum concentrations between $1 \times 10^{-7}$ and $1 \times 10^{-4} \mathrm{M}$.

\section{LDH Extraction techniques- Standard biochemical enzyme} lsolation techniques (LeJohn and Stevenson 1975) could not be used to assay the activity of Scenedesmus lactate dehydrogenase. Metal speciation would not be maintained in a multi-step, mult1-buffer process. The first goal was to determine if LDH activity could be analyzed if the cells were gently ground. Scenedesmus quadricauda was grown in enriched Fraquil ( $\left.2 x \mathrm{NaNO}_{3}, \mathrm{~K}_{2} \mathrm{HPO}_{4}\right)$. For each sample, 100 nl of a week old culture was centrifuged (International Centrifuge Co.) at 2000 rpm for five minutes. The pellet wae trensferred to a cold (5 OC) mortar. Three milliliters of $50^{\circ} 1 \times 10^{-1} \mathrm{M}$ Tris were added and the cells were ground for two minutes. The mixture was centrifuged at $2000 \mathrm{rpm}$ 
for five minutes. Two milliliters of the supernatant was transferred to a cuvette. The change in absorption was monitored for five minutes. $0.25 \mathrm{ml}$ of $\mathrm{NADH}$ was added and the sample was monitored for an additional five minutes. These stepe were taken to determine the background change in NADH concentration. The enzyme activity assay was begun by adding $0.25 \mathrm{ml}$ of the pyruvate solution. The change in absorption was monitored for thirty minutes.

LeJohn and Stevenson (1975) suggest that LDH can be extracted in a $\operatorname{Tr} 1 \mathrm{~s}\left(1 \times 10^{-1} \mathrm{M}\right)$-acetate $\left(2 \times 10^{-3} \mathrm{M}\right)$ buffer. This solution was used in the test of another extraction technique. $100 \mathrm{ml}$ of culture was filtered through a $25 \mathrm{~mm}$ glass fiber filter (Gelman Sciences, Type A/E). The filter and three milliliters of the Tris-acetate buffer were placed in a $15 \mathrm{ml}$ glass tissue grinder (Wheaton Scientific). Some of the samples were ground using an electrical motor driven teflon pestle, while other were ground by hand using a ground glass pestle. Various grinding times were tested. After a sample had been ground, the mixture was centrifuged at 2000 rpm for five minutes. The LDH activity was assayed using the method described above.

As some enzymes are inactive or preaent in low concentration in the absence of their substrate, the effect of pre-exposure to pyruvate was tested. A stationary phase culture was split into two $100 \mathrm{ml}$ samples. One milliliter of $2.27 \times 10^{-4} \mathrm{M}$ pyruvate was added to one of the samples. 
After twenty-four hours both cultures were assayed for LDH activity. The filtration technique discussed above was used. In all cases the filters were hand ground for one minute.

Sullivan and Volcont (1976) explain how internal enzymes of algae can be assayed by dissolving the cell nembrane. Two solvents were tested. In the first method, $0.001 \mathrm{v} / \mathrm{v}$ toluene in $1 \times 10^{-1} \mathrm{M}$ Tris was prepared. $100 \mathrm{ml}$ of a stationary phese culture was centrifuged and the peilet was added to five milliliters of the Tris-toluene solution. The sample was mixed for five seconds in a vortex test tube mixer every 30 seconds for five minutes. The sample was then centrifuged ( $2000 \mathrm{rpm}$, five minutes). The toluene-Tris solution was removed by suction and replaced with five milliliters of a $1 \times 10^{-1}$ Tris solution. Pyruvate and NADH $(0.5 \mathrm{ml}$ each) was added and the $2.5 \mathrm{ml}$ of the sample was filtered into a spectrometer cuvette. After one hour the remainder of the sample was filtered and its absorption recorded. In the second method, two drops of the detergent Triton-x was added to five milliliters of a culture. After five minutes of gentle mixing, the anple was centrifuged ( $2000 \mathrm{rpm}$, five minutes). The Triton-x solution was replace with five millilitera of the Tris buffer. The above assay method was repeated. 
RESULTS

Isolated LDH Experiments- The experiment using $1 \times 10^{-1}$ Tris Indicates that a pyruvate concentration of $2 \times 10^{-5} \mathrm{M}$ was required to saturate the isolated lactate dehydrogenase. The diluted enzyme in the absence of copper lost twenty five percent of its activity in twenty four hours. In the presence of copper less of a decrease was noted.

LDH could be maintained in a 1 ×10-3 M Tris solution, but a an assay could not be run at this buffer concentration. Table 11 shows the results of copper exposure. All the copper concentrations tested had some effect on enzyme activity. $1 \times 10^{-8} \mathrm{M}$ copper had little effect over the first elght hours, but after twenty four hours the activity was lower than the control rate. At time zero, the activity of the enzyme exposed to $1 \times 10^{-7} \mathrm{M}$ copper was only seventy five percent of the control. The activity continued to decrease with time. There was no activity after twenty four hours. At time zero the LDH exposed to 1 $\times 10^{-6} M$ copper had an activity of forty percent of the control: No activity was found at eight hours. At a copper concentration of $1 \times 10^{-5} \mathrm{M}$, the time zero activity was twenty five percent of control. There was total inactivation at thirty minutes. Higher copper concentration caused an immediate inactivation of LDH. LDH activity did not depend on aluminum concentration. Samples exposed to low aluminum concentration had activities lower 
than control, while those exposed to $1 \times 10^{-5}$ and $1 \times 10^{-4} \mathrm{M}$ aluminum had activitiea higher than control after twenty four hours.

LDH Extraction techniques- None of the extraction methods tested were effective. Although activity could be determined in some samples, reproducible data wes not obtained. Pre-exposure to pyruvate did have a noticeable effect. The measured change in absorption was 70-80 times greater than the pyruvate free sample, but the absorption increased instead of decreased as expected. This indicates another enzyme system was activated by the addition of pyruvate.

\section{CONCLUSION}

Internal and external enzymes should have different responses to metal toxicity. My goal was to investigate the effect of the aquatic chemistry of aluminum and copper on the activity of lactate dehydrogenase in Scenedesmus. Resulta obtained for this internal enzyme were to be compared to resulta using the external enzyme alkaline phosphatase. Experiments were performed in an effort to develop an extraction technique that would allow the reproducible measurement of LDH activity while maintaining conditions suitable for trace metal atudies. None of the techniques attempted produced consistent results. 


\section{REFERENCES}

Baker, Joen and Schofield, Carl 1982. Aluminum toxicity to fiah $1 \mathrm{~s}$ acidic water. Water, A1r, Soll Poll. 18. 289-309

Bold, H. and Wynne, M. 1978. Introduction to the algee: structure and reproduction. Prentice-Hall Inc.

Burrows, W.D. 1977. Aquatic aluminum: chemistry, toxicology, and environmental prevalence. CRC Critical Reviews in Environmental Control, 167-216

Cohen and Wilson 1966. Messurements of zinc dissociation constants of alkaline phosphatase from E. Col1 with zinc ion buffer. B10chen. 5(3) 904-909

Colemen, Joeseph and Gett1ns, Peter 1983. Molecular properties and mechanism of alkaline phosphatase. in Zinc Enzymes, Thomas Spiro ed., Wileyinterscience publication. Chep. 5

Cronan, Chrlatopher and Schofield, Carl 1979. Aluminum leaching response to acid precipitaion: effects on high-elevation watersheds in the Northeast. Sclence 204(20) 304-305

Currie, David and Kalft, Jaap 1984a. A comparison of the abilitiea of freshwater algae and bacteria to aquire and retain phosphorus. L\&O 29(2) 298-310

Currie and Kelft 1984b. The relative importance of bacterioplankton and phytoplankton in phophorours uptake in freshwater. L\&O 29(2) 311-321

Davey, E., Morgan, M. and Erickson, S. 1973. A blological measure of the copper complexation capacity of seawater. L\&O 18(6) 993-997

Dililion, P., Yan, N. and Harvey, H. 1984. Acidic deposition: effects on aquatic ecosystems. CRC Crit. Rev. Env. Control 13(3), 197-194

Driscoll, C. 1984. A procedure for the fractionation of aqueous aluninum in dilute acidic waters. Intern. J. Environ. Anel. Chem. 16 267-283

Driscoll, C., Baker, J., Blsogni, J., and Schofield, C. 1984. Aluminum speciation in dilute acidic surface waters of the adirondack region of New York State. in Geological aspects of acid depostion. Bricker, 0 . ed Butterworth Publishers, Chap 4 55-75 
Fontaine, Thomas 1984. A non-equilibrium approach to modeling metal speciation in acid, aquatic systems: theory and process equations. Ecological Modeling 21. $287-313$

Foy, C., Chaney, R., and White, M. 1978. The physilogy of metal toxicity in plants. Annu. Rev. Plant Physiol. 29: $511-566$

Gamble, Donald, Schnitzer, M., Kerndorff, H, and Langford, C. 1983. Multiple metal ion exchange equilbria with humic acid. Geochimica et Cosm. Acta 47 13111323

Gatcher, Ron, Davis, Joan, \& Mares, Antonio 1978. Regulation of copper availability to phtoplankton by macromolecules in lake water. E.S,\&T, 12 1416-1421

Giesy, J P 1983. Metal binding capacity of soft, acid, organic- rich waters. Toxicology and environ. Chem. 6 203-224

Giesy, John, Newhall, Avis, and Leversee, Gordon 1983. Copper speciation in soft, acid, humic, waters: effects on copper bioaccunulation and toxicity to

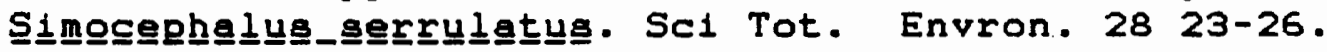

Gillespie, Paul and Vaccaro, Ralph 1978. A bacterial bioassy for measuring the copper-chelation capacity of seawater. L\&O $23(3) \quad 543-547$

Goldman, Charles and Horne, Alexander 1983. Limnology. McGraw-Hill. Chap 9.

Haug, Alfred 1984. Molecular apsects of aluminum toxicity. CRC Critical reviews in plant science. $1(4)$ 345-373

Helliwell, Stuart 1983. Speciation and toxicity of aluimium in a model fresh water. Sci. \& Tech. Letters 4 141-144

Huntsman, S. and Sunda, W. 1980. The role of trace metals in regulating phtoplankton growth: with emphasis on Fe, $M n$, and $C u$. in Physlological Phytoplanteton Ecology, Morris, I. ed.

Johnson, Noye 1984. Acid rain neutrilization of by geological materials. In Geological aspects of acid depostion. Bricker, 0 . ed. Butterworth Publishers Chap 3 37- 53 
Johnson, N., Likens, G., Feller, M.. \& Driscoll 1984. Acid rain and soil chemistry. Sclence 225 14241425

Kerndorff, H., and Schnttzer, M., 1980. Sorption of metals on humic acid. Geochimica Acta. 44 1701-1708

Kuenzler, E. and Perras, J. 1965. Phosphatases of marine algee. Biol. Bull. 128: 271-284

Lazerte, B.D. 1984. Forms of aqueous aluminium in acidified catchments of central Ontario: a nethodolgical analysis. Can J Fish. Aquat. Sci. 41 766-776.

Lehninger, A. 1982. Prinicples of Biochemistry. Worth Publ.

LeJohn, H.B. and Stevenson, R.M. 1975. D(-)-Lactate Dehydrogenase from Fungi. Methods in Enzymology vol XLI, $W$. Wood ed. Acedemic Press.

Mcknight, Diane 1981 . Chemical and biological process controlling the response of a freshwater ecosystem to copper stress: a feild study of CuSo4 treatment of Mill Pond Reservior, Burlington, Massachusettes. L \& $026(3) \quad 518-531$

McKn1ght, D. Chisholm, S. Herleman, D. 1983. CuSO4 treatment of Nuisance blooms in drinking water reserviours. Environ. Management 7 (4) 311-320

Mcknight, D. and Morel, F. 1979. Release of weak and strong copper complexing agents by algae. L\&O $24(5)$ 823-837

Morel, F. Rueter, J. Anderson, D. and Guillard, R. 1979. Aquil: a chemically defined phytoplankton culture medium for trace metal studies. J Phycol. 15. 135-141

Ochiai, E. 1977. Bloinorganic Chemistry: an introduction Allyn \& Bacon Publ.

Perdue, E.M. 1979. Solution Thermochemistry of Humic substances. In Chemical Modeling in aqeous systems. E.A. Jenne ed.. Am. Chem. Soc. symposium Chap 5, $99-114$

Perdue, Edward, and Lytle, Charles 1983. D1stribution model for binding of protons and metal lons by humic substances. ES\&T 17 (11) 654-660 
Petersen, Richard 1982. Influence of copper and $z i n c$ on the growth of a freshwater alga, Scenedesemus gue speciation.. ES\&T $16 \quad 443-447$

Peterson, H., Healey, F.P., and Wagermann, R. 1984. Metal toxicity to algae: a highly $\mathrm{pH}$ depedent phenomenon. Can. J. Fish. Sci. 41, 974-979

Rothstein, A. 1959. Cell membrane as site of action of heavy metals. Fed. Proc. 18,1026-1038

Rueter, John 1983. Alkaline phosphatase inhibition by copper: implications to phosphorus and use as a biochemical marker of toxicity. L\&O $28(4)$ 743-748

Rueter, J. and Morel 1981. The interaction between zinc deficiency and copper toxicity as it affects the

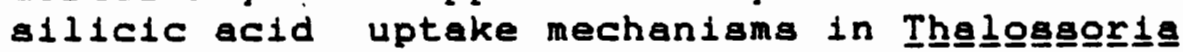

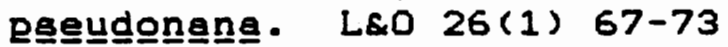

Saar, R. and weber J., 1982. Fulic acid: modifier of metal-ion chemistry. E,S, \& T 16 (9)510-517

Schofield, Carl and Trojnar, John 1980. Aluminum

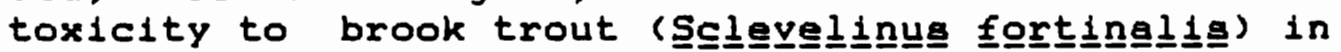
acidified watera. in polluted Rain. Toribara, T. ed. Plenum press 341-366.

Shaw, T. and Brown V. 1973. The toxicity of some forms of copper to rainbow trout. Wat. Res. 377-382

Smith and Martell 1975. Critical Stability Constants, vol 2 \& 3. Plenum Press.

Steemann-Nielsen and Wium-Andersen 1970. Copper ions as polsons in the sea and freshwater. Marine B10. 6 93-97

Sullivan, C. and Volcani, B. 1976. Role of silicon in diatom metabolism. VII. Silicic acid-stimulated DNA synthesis in toluene-permeabilized cells of

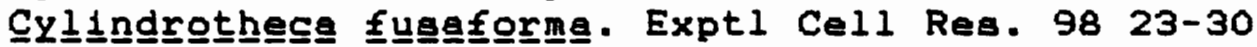

Sunda, WG and Lewis; J. 1978. Effect of complexation by natural organic ligands on the toxicity of copper to

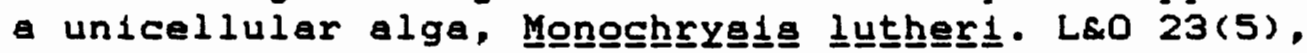
870-876

Vallee, B.L. 1959. Metal and enzyme interactions: corrolation of composition, function, and atructure. Physiol. Rev. 39, 443. 
westall, J.C. 1985. MICROQL: a chemical equilibrium program in PASCAL. Oregon State Univ.

Westall, J.C. 1979. MICROQL: a chemical equilibrium program in BASIC. Swisa Fed. Insit. Tech.

Westall, J.C., Zachary, J.L., and Morel, F.M. 1976.

MINEOL: a computer program for the calculation of chemical equilbrium composition of aqueous systems. Mass. Inst. Tech., R.M. Parsons Lab. Tech Note 18 